\title{
Determinants Variables for Women's Participation in Non-Agricultural Livelihood Diversification Strategies in Ethiopia: A Logistic Regression Model Analysis
}

\author{
Eyayu Kasseye Bayu \\ Department of Gender and Development Studies, College of Social Sciences and Humanities, University of \\ Gondar, Ethiopia
}

\begin{abstract}
Women represent almost half of the world population; the same is true in rural Ethiopia. However, in many countries, gender-based stereotypes and discrimination deny rural women equitable access to and control over land, labor, asset and opportunities for employment and income-generating activities. Having this rationale, very little is known about the determinants of women's participation in non-farm livelihood activities in the rural economy of Ethiopia. Hence, the general objective of this study was to examine the determinants of women's participation in non-farm livelihood diversification strategies in Shebel Berenta Woreda, Amhara Region. Mixed research method with explanatory research design was employed for data collection and data analysis. The questionnaire survey was collected from 267 systematically selected women from randomly selected four rural kebeles in the study area. Descriptive and inferential statistics were used to analyze the collected quantitative data. Binary logistic regression model was employed to identify the factors that determine women's participation in NFA in the study area. The result of binary logistic regression model showed that women's age, marital status, educational status, land size, credit, non-farm training, and having triple gender roles were the major determinants of women's participation in NFA in the study area. In line with the problems identified, the local government should work on awareness creation and education, provision of support, built local infrastructure, provision of credit and training to increase their participation in non-farm livelihood diversification.
\end{abstract}

Keywords: Determinants; Non-farm, livelihood diversification, Participation, Logistic

DOI: $10.7176 / \mathrm{JPID} / 58-04$

Publication date: January $31^{\text {st }} 2021$

\section{INTRODUCTION}

Women represent almost half of the world population (Holmes and Jones, 2010). In this regard, Sara (2007) indicated that in rural Ethiopia, women comprise almost half of the population. However, in many countries, gender-based stereotypes and discrimination deny rural women equitable access to and control over land, labor, asset and opportunities for employment and income-generating activities (UN, 2008). Similarly, Goitom and Kalpana (2017) stipulated that women in Ethiopia occupy the low status in the society; they are discriminated both socially and economically. Moreover, they have also less access to education and income generating facilities than men due to cultural restrictions. Sara (2007) also strengthen that even though, women are vigorously involved in all socio-economic and cultural aspects of society; the effects of poverty have been more serious for women than men. Hence, due to lack of destiny of access to land and formal employment, women are involved in casual, informal and unregulated labor as way of generating income. Principally, as a survival strategy and as a means of improving their livelihood, the rural communities in general and women in particular either engaged in various non-farm and/or off-farm activities or migrated to the nearest urban areas.

Concerning to such cases, in several categories of income-generating jobs, women in the rural non-farm employment sector are predominantly in the informal economy and this is associated with serious concerns over women's rights and social protection (Fontana and Paciello, 2009 cited in UN, 2009). Yet, the productive role especially non-farm work done within the household by women has been ignored and not much attempt has been made to incorporate in the value of such activities within the national accounts (UNDP, 1995 cited in Ojulu, 2015). Thus, it needs to conduct a study to make visible women' non-farm work both in home and outside in rural areas. On the other ways, women play an important role if they involve in non-farm activities to increase household income, improve family welfare and nutrition. However, high return non-farm activities have certain requisites to enter in this activity includes among others education, skills and investments (IFAD, 2004 cited in Worku, 2016). In line with this, Davis and Bezemer (2004) also strengthen and state that in several societies being female represents an important 'barrier to entry' to non-farm employment. To this effect, participation in non-farm activities is determining through the possibility to overcome the required entry barriers. When entering in nonfarm activity requires substantial investments, liquidity constraints will hamper household's heads with restricted assets to enter in these activities. The ability of households' heads to overcome these entry barriers depends on their capacity variables such as collateral requirements, market imperfections and differences in repayment capacity make credit constraints more severe for poor households than for rich (Davis et al., 2009). Even though, 
they are involving in non-farm activities; their participation into non-farm activities is determined via different factors and deep-rooted challenges in the study area.

\section{Objectives of the Study \\ General Objective of the Study}

The general objective of this study was to examine determinants of women's participation in non-agricultural livelihood diversification strategies in Shebel Berenta Woreda, East Gojjam Zone, Amhara National Regional State.

\section{Specific Objectives of the Study}

- Examine factors that determine women's participation in non-agricultural livelihood activities in the study area

\section{Research Questions}

- What are the factors that determine the participation of women in non-agricultural livelihood activities in the study area?

\section{Significance of the Study}

Barrett et al.,(2001) study showed that it is difficult to imagine an effective rural poverty reduction and food security strategy for Africa that does not aim to harness with the potential of the non-farm sector. Here again, Boserups (1970) also indicated that economic development is unthinkable without looking the contribution and role that played by women both in the productive and reproductive spheres. Then, we should start to be acquainted with both on recognizing the essence of non-farm and productive roles of women or the types of non-farm activities that are pursue by women and recognizing their participation in the sector since women often play multiple roles in the society. Thus, this study would have the following importance: First, the successful accomplishment of this study would provide information for local government that acts upon to improve the livelihood prospects of women from non-farm activities. Secondly, the findings of this study would use as a guideline information for policy maker and local development actors and implementer to target women in rural non-farm economy. Thirdly, the outputs of this study might contribute to theoretical understanding in relation to women's involvement in various activities in the non - farm sector. In addition, this study would provide clues on knowledge of the nature and concept of non-farm activities to promote women's participation for the future in the study area.

Principally, this study hopes to provide necessary analytical insights for targeting NFA, which is pursue by women for Technic, Vocational and Enterprises Development office, Agriculture and Rural Development office, Trade, Industry and Market Development office and Women and Children affairs office in the study area. Fourth, it might also give information to the next work for forthcoming researchers who would like to conduct detailed and comprehensive studies in the rural areas and other study area concerning to NFA. Lastly, examining and identifying the factors that influencing women's participation in NFA would help for policy consumption.

\section{Scope of the Study}

Geographically, the study was conducted in rural kebeles, which are found in Shebel Berenta Woreda; it did not include urban kebeles of the woreda. Conceptually, the coverage of the study was limited to only on the women's participation in NFA in selected Kebeles with in Shebel Berenta Woreda. Although there are different factors that determine the participation of women in non-farm activities, but this study was delimited to four general factors; namely, demographic factors, institutional factors, locational factors and socio-economic factors. Concerning the target group, the study was delimited to women both in male- headed and female headed- households in order to examine their status and for generalizing women were included as the scope of the content in the study area.

\section{Limitations of the Study}

This study has limitations that future studies need to address. Firstly, sample women for this study were confined to rural area; but this is not to means that the problem of undermining women non-farm work is restricted to rural areas only. More importantly, non-farm sector in many urban parts of Ethiopia is not well studied. So, researchers will address the urban women's participation in the future. On the other hand, comparing men and women's participation in non-farm activities did not do this study. Rather, the study dealt with the determinants of participation of women only because addressing large sample was difficult when the case of men was added for this study. Hence, studies can be done by comparing the participation of men and women in NFA in the future. Due to the heterogeneity of non-farm activities, this study only addressed sectorial, functional and locational classification regarding women's participation by taking non-farm as a one rural economic activity; but each classification might be an independent research for the future forthcoming researchers. It is worthy note that, this study also did not address all rural Kebeles, which is found in Shebel Berenta Woreda regarding women participation in NFA rather than concentrated on four Kebeles due to the scarcity of time and resources. 
Nevertheless, to compensate this limitation, the researcher took large sample size and used mixed research approach to comprehensive analysis of the problem.

\section{Operational Definitions of Terms}

An activity: as Mphande (2016) clearly noted that activities--which encompasses what they do. Some of the activities that fall under rural livelihood include: Apart from agriculture, it also included non-agricultural activities: wage of labor, trading and hawking, artisan works, for example, weaving and carving, pottery, bakery and basket making. Activities comprise all the ways in which household members utilize their non-leisure time to support their livelihoods. It includes work, care, employment, entrepreneurship, trade, and a range of other activities. The engagement on activities both requires assets and may increase households' stock of assets as Davis and Bezmer (2004) stipulated.

Non-farm activity: refers all economic activities undertaken at home or away from home, either by selfemployees or by wage laborers, other than production of primary agricultural commodities (crop production and livestock production, forestry and fishery). Non-farm activity also refers to an activity that is associated with wage work or activity undertaken by wage laborers and self-employment activity undertaken by hired employees or without hiring employees that is not in agriculture but located in rural areas (Lanjouw and Lanjouw, 2001).

Participation: refers the involvement of women in non-farm activities or the act of taking part an activity or processes by which women have shared from the involvement in non-farm work. It is viewed as the involvement of women through devoting their time for non-farm activities by considering either as a main job or as alternative tasks. Participation often means involvement in externally conceived activities via contributions and benefits (Davis, 2003).

Gender Roles: a set of behaviors, norms, acts, roles and beliefs constructed socially and culturally to be exercised by the respective sexes. It is a learned behavior in a given society/community or other social group that condition the gender division of labor, i.e. which activities, tasks and responsibilities are perceived as male or female. What women and men are expected to do and how they are expected to behave towards each other. Gender roles change over time in response to changing community circumstances and changing ideas about what is acceptable and not acceptable behaviors and roles. Gender roles and characteristics affect power relations between men and women at all levels and can result in inequality in opportunities and outcomes for some groups (Kabeer, 1994).

Livelihood: a means of securing the necessities which comprise of the capabilities, assets (including both material and social resources) and activities required for a means of living (Ellis, 2000).

Triple gender roles: are the productive, reproductive and community managing roles assigned to women in gender-based division of work. The productive roles are those income-generating duties of women; reproductive roles refer the biological reproduction as well as labor reproduction responsibilities and community roles are tasks they do in social life like service provisions and voluntary works. Historically, women's productive roles such as income-generating activities have been ignored or under-valued, particularly in the non-farm sector and subsistence agriculture since women's labor is undervalued (Reeves and Baden, 2000).

Kebele: is the smallest administrative unit in the current administrative arrangement of the Federal Democratic Republic of Ethiopia

Kolla: an agro-ecological zone with relatively warm weather condition

Wereda: is an administrative unit comparable to a district, which covers a number of kebeles and less than Zone. Woyina-Dega: an agro-ecological zone having an average-between Dega and Kolla weather condition.

\section{Conceptual Framework of the Study}

Based on the review of related literature, conceptual framework for this study is developed. This particular study is emphasis on demographic factors (age, marital status, family size, status of household head and educational status), socio- economic factors(membership of social groups, triple gender roles, farm size and access to water supply), institutional factors (access to non-farm training and access to credit services) and locational (distance to the nearest main road and distance to the nearest main product market) factors that determine the participation of women in non-farm activity (NFA). All in all, the focus and scope or boundary of quantitative part of this study is summarized on the following conceptual framework. 


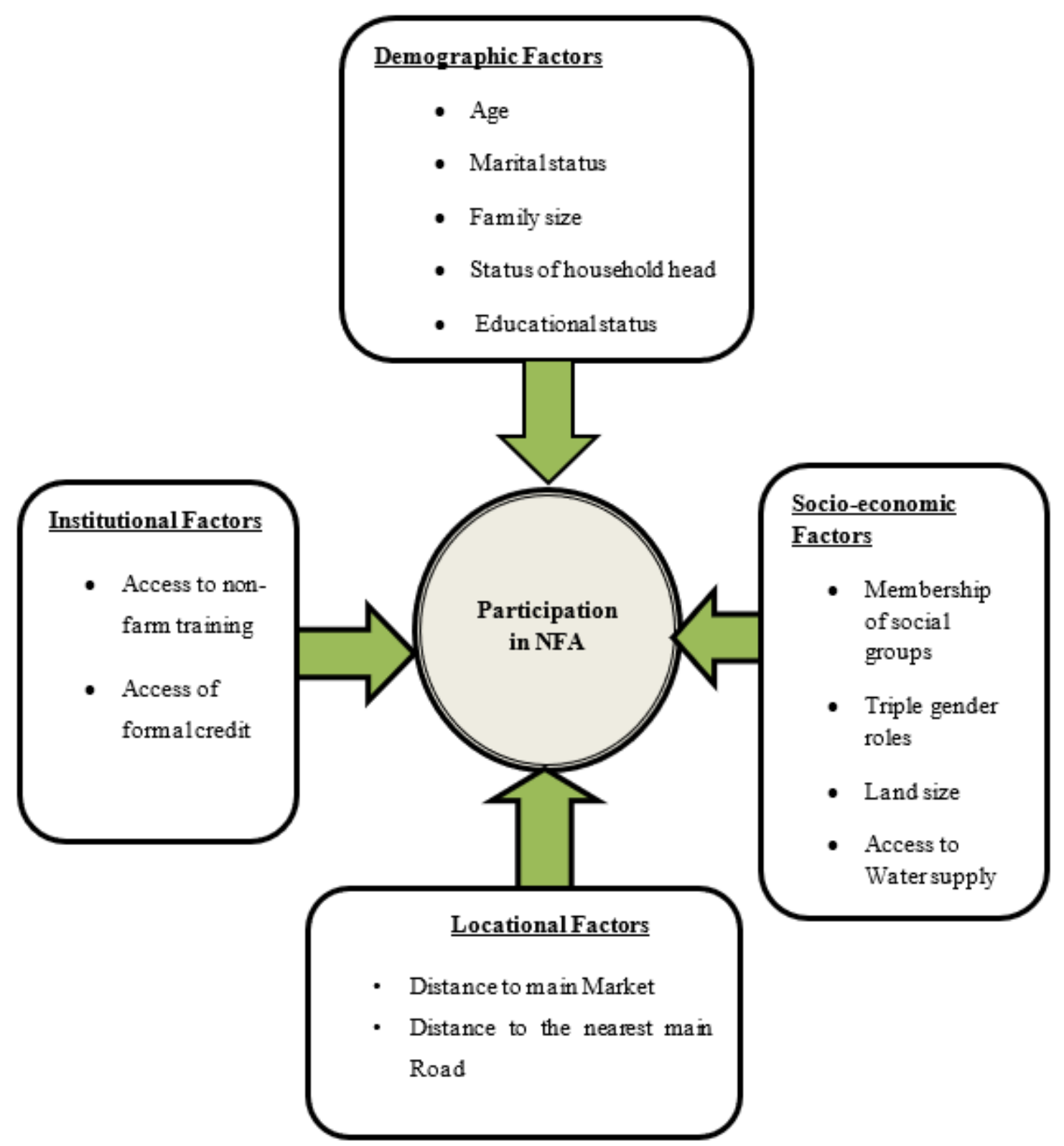

Figure .1: The schematic diagram showed the relationship between the dependent variable and independent variables.

\section{RESEARCH METHODOLOGY \\ Description of the Study Area \\ Location and Topography}

Geographically, Shebel Berenta Woreda is one of the Woredas' located in East Gojjam Zone, situated in the Northcentral highlands of Ethiopia in the Amhara National Regional State. It is extending between $10^{\circ} 15^{\prime} \mathrm{N}$ to $10^{\circ} 30^{\prime}$ $\mathrm{N}$ degrees latitude and between $38^{0} 15^{\prime} \mathrm{E}$ to $38^{0} 27^{\prime}$ degrees of longitude (CSA, 2007 cited in Adamu, 2010). It is found at a road distance of $293 \mathrm{~km} \mathrm{NE}$ of Addis Ababa, capital city of Ethiopia. Shebel Berenta woreda is bordered on the South-West by Dejjen woreda; on the North-West by Enemay woreda; on the north by Enarj Enawga woreda, and South and South- East by Abay River Gorge, which separates it from Oromia region. The major town of Shebel Berenta woreda is Yedwuha (Hugo Rami, 2002).

\section{Landscape and Agro-ecology}

Shebel Berenta Woreda covers a total land area of 89,714 hectares (ha). Topographically, $8.45 \%$ of the woreda is mountainous, $43.47 \%$ plain and $48.08 \%$ is valley. Its altitude ranges from $1800 \mathrm{~m}-2150 \mathrm{~m}$ above sea level. Shebel Berenta woreda has two agro-ecological zones with (72.3\%) Kolla and Woyina Dega (27.7\%). Based on land coverage, most part of the woreda are situated in the lowlands (Kolla) along the Abaye River Gorge, and are 
extremely depleted, deforested and eroded. Moreover, rainfall is highly seasonal in the woreda; vivid evidences and experiences indicated that almost $90 \%$ of the total annual rainfall received in the woreda elapses during summer only. The average annual rainfall ranges from $4000 \mathrm{~mm}$ to $1000 \mathrm{~mm}$ (Shebel Berenta Woreda Information and Communication affairs Office, 2017). With regard to temperature, the same thing is happening to rainfall conditions where the lowland is hotter and warmer as compared to the midland agro ecologies that enjoy mild or moderate temperature. The warmest and coldest months of the year occur in May and January having the maximum and minimum temperature records of $29.8^{\circ} \mathrm{c}$ and $9.4^{\circ} \mathrm{c}$ respectively. Thus, it is this variation in rainfall and temperature greatly influence the way of life of people and their economy (Adamu, 2010).

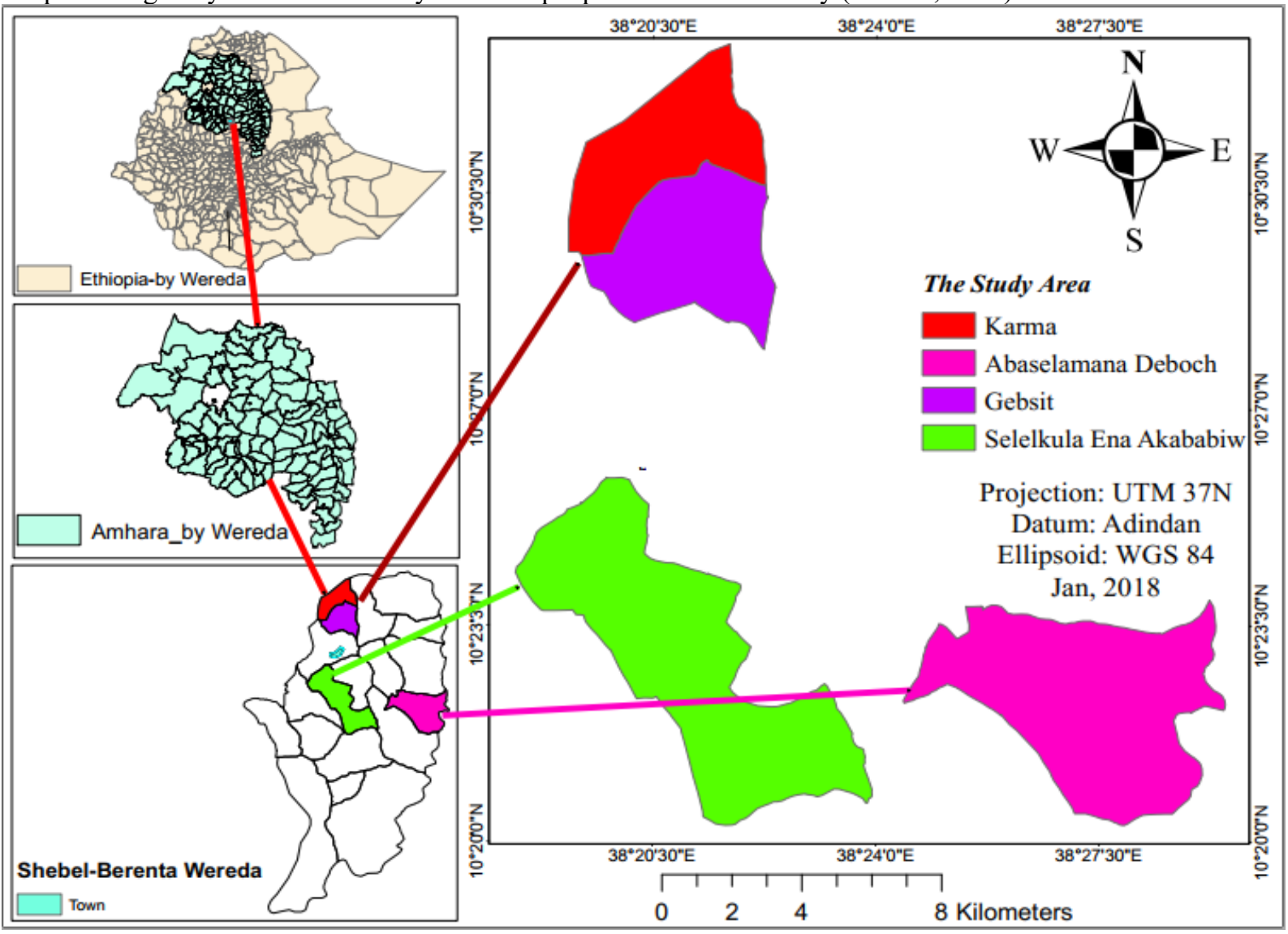

Figure.1. Location Map of the study area (Shebel Berenta Woreda and Selected kebeles).

\section{Demographics and Socio-Economic Characteristics of the Study Area Demography}

Shebel Berenta woreda is structured with 21 kebeles of which two are urban and 19 rural kebeles. The estimated total population of Shebel Berenta woreda is 129,156 of the total population of the woreda, which consists of 61,640 males and 67,516 females. Out of the total population of the woreda, 11,271 (4955 males and 6316 females) are urban dwellers and the remaining 117,885(56,685 males and 61,200 females) persons reside in the rural areas of the woreda. The 32,589 rural households counted in this woreda, out of which 22, 839 are male-headed households, and the rest 9,750 are female- headed households (Shebel Berenta Woreda Information and Communication affairs Office, 2017).

\section{Socio- Economic Characteristics of the Study Area}

Agriculture is the mainstay of the district livelihood activities for rural residents, which is characterized by subsistence crop production, it is mainly dependent on rainfall, which is erratic in nature and dominantly traditional farming system resulted in low- crop yields (Adamu, 2010). The available study by Hugo Rami (2002) also indicated that in 2002, it was judged to be one of four chronically food- insecure Woredas' in this part of the Amhara Region, due to much of their farmland being extremely depleted, deforested and eroded. Despite of this, the productive safety net program is still provided as preventive social protection. On the other hand, there is also the presence of non-farm activities, which is practiced by rural households; though still given to poor households. Trading, weaving, blacksmithing, carpentry, leatherwork and food for work are among non-farm activities in the rural kebeles of the woreda (Shebel Berenta Woreda Communication Affairs Office, 2017). 


\section{Research Method and Design of the Study}

The objectives of this research have demanded to generate both quantitative and qualitative data and taking into account this rationale, the study has applied a mixed research method. Principally, women have diverse experiences and practices in non-farm livelihood activities in rural areas. For instance, women participate in trading, pottery, sale of firewood and charcoal, private wage employment and public wage employment in the non -farm economy. In this regard, their participation in NFA is determined by different demographic, socio- economic, locational and institutional factors. Thus, the factors that determined their participation and extent in non-farm activities they undertake in rural areas were assessed by the quantitative research method through questionnaire and supplemented with interview and Focus group discussion. Therefore, to examine these issues, mixed research method was relevant to produce both statistical results and verbal results and to minimize some of the limitations of using single method. As given emphasis by Angell and Townsend (2011) when quantitative and qualitative research methods are used in combination in one study, they complement to each other and allow for a more complete analysis of the research problem. Several authors indicate the essence of mixed research approach. For instance, Carolyn and Isadore (2008) indicates that mixed research approach is defined as the class of research approach where the researcher mixes or combines quantitative and qualitative research methods into a single study rather than restricting or constraining researchers' choices. Moreover, Stephen and Kassim (2015) indicate that mixed research involves mixing and combining qualitative and quantitative research in single research studies. It is based on the philosophy of pragmatism (i.e., what works is what should be considered to be important to answer research questions). The qualitative and quantitative parts of a research study might be conducted concurrently (conducting both parts at roughly the same time) or sequentially (conducting one part first and the other second) to address a research question or a set of related questions. Then, taking in to account this and considering the nature of this research, sequentially explanatory research design used for this study, which applied as a mixed research method.

\section{Sampling Techniques}

The rationale for the choice of Shebel Berenta Woreda for this study area is based on the 2007-2009 E.C woreda report, which stated the woreda has severe problems of low productivity of agriculture, food insecurity and continuous existence of drought and it also needs other ways to sustain the livelihood of rural households. Thus, provide a clue that about NFA is used as the best alternative ways to recover from vulnerability and risks is opted. Principally, based on the observation and experience in the study area, there is a deep-rooted problem of ignoring women's non-farm work decisions so it needs to investigate the problems of women for further intervention. Here, a woman from both male- headed and female-headed household were used as the primary unit of analysis. In this study, the list of male headed and female-headed households were obtained from each kebele administration.

The researcher has employed multi -stage-sampling techniques to select sample women. In the first stage, stratified random sampling was employed to select rural kebeles; this is because the rural kebeles of Shebel Berenta woreda is already categorized into two agro- ecological zones of Woyina Dega and Kolla. Then, from these strata, four sample kebeles (Selelkula and Gebsit) from Woyina-Dega, while (Karma and Abaselma ena Deboch) kebeles from Kolla were selected randomly out of the total of 19 rural kebeles in the study area by taken agro ecology into account.

In the second stage, stratified random sampling technique was employed to select male-headed and femaleheaded households from each kebele's considering there was a woman in the male-headed household. Proportional stratified random sampling was employed in accordance with the size of the kebele. Then, each kebele's list of male- headed and female-headed household were used as sample frame. Finally, systematic random sampling technique was applied to select sample women from each kebele based on the lists that was obtained from the respective kebele's administration office.

\section{Sample Size and Sample Size Determination}

There are a number of strategies in determining a sample size including using a census for small populations, imitating a sample size of similar studies, using published tables, and using formulas to calculate a sample size(Israel,1992). Among such strategies, the researcher was used formula based on the real context of this study. In applying formula, one has to consider certain factors to determine the appropriate sample size such as the level of precision, the level of confidence or risk, and the degree of variability in the attributes being measure in addition to the purpose of the study and population size as noted by Israel (1992). Using formulas to calculate a sample size can provide a useful guide to determining the sample size of proportions (Amugune, 2014).

As quoted by Amugune (2014); Singh and Masuku (2014), Cochran (1963) suggested the most commonly used formula for a questionnaire survey studies sample size determination when the population is large and the needed representative sample is to analyze proportion. The formula is:

$$
\mathrm{n} 0=\frac{\mathrm{z}^{2} \mathrm{pq}}{\mathrm{e}^{2}}
$$


Where, $\mathrm{n} 0=$ the required numbers of sample

$\mathrm{z}=$ the value of the desired confidence level or confidence interval $(95 \%=1.96)$

$\mathrm{e}=$ the desired level of margin error or precision

$\mathrm{p}=$ estimated variability or proportion of an attribute in the population $(50 \%=0.5)$

$\mathrm{q}=1-\mathrm{p}$

Accordingly, the researcher would like to use $95 \%$ confidence level $(z=1.96)$, the maximum variability among the population (50\%), and $\pm 6 \%$ margin of error/precision by looking the expected criteria.

When we apply the formula, $\mathrm{n} 0=\frac{(1.96)^{2} 0.5(1-0.5)}{(0.06)^{2}}=\frac{3.8416 \times 0.5 \times 0.5}{0.0036}=266.77 \approx 267 \quad$ Therefore, the required sample sizes of this study were 267 women. But, the question is how can these individuals be selected? This sample size allotted to the four kebeles was based on proportionate sampling method. Though with this method each kebeles was fairly represented, proportional allocations of the sample have been made based on the size. This sample size was allotted to four kebeles using proportionate stratified sampling formula.

Through this formula, each kebeles was fairly represented as follows:

1. Sample size of Selelkula ena Akababiw $=2132 * 267 / 5681=100$ women

2. Sample size of Gebsit $=1369 * 267 / 5681=64$ women

3. Sample size of Karma $=725 * 267 / 5681=34$ women

4. Sample size of Aba Selma ena Deboch $=1455^{*} 267 / 5681=69$ women.

As already mentioned above, among the target population of 5681(women in male headed and female-headed) the researcher took 267 respondents as calculated based on the above formula. Lastly, the required sample households were selected via systematic random sampling within each kebeles, based on the lists every $\mathrm{i}^{\text {th }}$ element (i.e every $21^{\text {th }}$ ), until to reach the required sample size after the first respondents selected randomly.

Table 3.1 The Summary of sampled women by Kebelles.

\begin{tabular}{|l|l|l|l|l|l|l|l|}
\hline \multirow{2}{*}{ Sample Kebelles } & Stratum & \multicolumn{2}{l}{$\begin{array}{l}\text { Number of households in each } \\
\text { Kebelle }\end{array}$} & \multicolumn{2}{l}{$\begin{array}{l}\text { Number of sampled women taken from } \\
\text { each Kebelle }\end{array}$} \\
\cline { 2 - 8 } & & $\begin{array}{l}\text { Male } \\
\text { headed }\end{array}$ & $\begin{array}{l}\text { Female } \\
\text { headed }\end{array}$ & Total & $\begin{array}{l}\text { Male- } \\
\text { headed }\end{array}$ & $\begin{array}{l}\text { Female- } \\
\text { Headed }\end{array}$ & Total \\
\hline $\begin{array}{l}\text { Selelkula ena } \\
\text { Akababiw }\end{array}$ & $\begin{array}{l}\text { Woyina- } \\
\text { Dega }\end{array}$ & 1396 & 736 & 2132 & 66 & 34 & 100 \\
\hline Gebsit & $\begin{array}{l}\text { Woyina- } \\
\text { Dega }\end{array}$ & 846 & 523 & 1369 & 40 & 24 & 64 \\
\hline Karma & Kolla & 508 & 217 & 725 & 24 & 10 & 34 \\
\hline $\begin{array}{l}\text { Abbaselma ena } \\
\text { Deboch }\end{array}$ & Kolla & 975 & 480 & 1455 & 46 & 23 & 69 \\
\hline Total & & 3725 & 1956 & 5681 & 176 & 91 & 267 \\
\hline
\end{tabular}

Source: Field survey, 2018

Data Collection Instruments

Interview schedule, key informant interviews, observation and FGDs were the data collection instruments used to gather primary data as shown here under.

Questionnaire survey: Questionnaire is a set of carefully designed questions given in exactly the same form to a group of people in order to collect data about some topic(s) in which the researcher is interested (Victor, 2006:256). Composed of both closed ended and open-ended types of questions in the questionnaire survey was prepared and used to collect primary data from survey respondents. The questionnaire survey was prepared based on and to get information on the extent of women's participation in NFA, women employment status in NFA and factors affecting their participation in NFA. It was prepared in English and translated into Amharic because respondents' local language is Amharic. Before the questionnaire survey has been administered, the draft was evaluated and unnecessary details and vague questions were removed.

Pretest was conducted to detect the weakness in design and instrument, and to provide alternative data for the selection of probability sample as well as to ensure that the items in the questionnaires bear the same meaning to all respondents and to assess the average time that is required to administer an instrument. Hence, pilot test was carried out on 20 randomly selected women to ensure the validity, to avoid vague or ambiguous questions and to easily understand by the respondents. This helped to refine the questions. The researcher assigned five enumerators based on knowing their residence place and local community and experience's, and one supervisor, all speaking the local language conducted the survey. The enumerators were first trained by the researcher about how to present and explain each question to respondents. They were also advised to inform each respondent about the purpose of the survey before starting the actual survey. A total of 267 interview schedule were administered from respondents' via gone into respondents' homestead and all were returned for further analysis.

Focus Group Discussions (FGD): focus group discussion is a type of group interview that concentrates on an in- 
depth discussion of a particular theme or topic. In most cases, the group is made up of people who have particular experience or knowledge about the subject of the study or who have a particular interest in it (Kothari, 2004). Hesse-Biber and Leavy (2004) also delineates focus group as a distinct method of qualitative interviewing in that multiple participants are interviewee in the context of a group. It is often used to give voice to group participants. The researcher used focus group discussion which for a dialogue among participants and stimulates them to openly express their views on the issues raised. Gillham (2000) states that focus group discussion using semi structured questions allows researchers to look into more deeply into the research issues and develop new lines of inquiry that arise from interviews.

Taking in to account this therefore, four FGD were carried out involving eight women in two groups and six in two groups using a checklist of semi-structured questions. Issues that were addressed in the focus group discussion were on type's non-farm activities that women pursue, challenges they faced and opportunities they had to participate in NFA. The time for discussion took from one to one and half hours. Late afternoon and Sunday (the whole day), (monthly day of St.Michael, St.Virgin Mary) were convenient times for the discussions. The group discussions were conducted via Amharic language, since it is medium of communication in the area, with an assistant active note taker who was given proper orientation on how to organize minutes. The researcher largely acted as a moderator during the discussions. Notes taken from a group discussion were summarized and any key and important issues arising in one group discussion were used for further discussion in the following group discussions. . The researcher largely acted as a moderator during the discussions. Notes taken from a group discussion were summarized and any key and important issues arising in one group discussion were used for further discussion in the following group discussions.

Key Informant Interviews: In this study, key informant interview was one of research tools for data collection: an attempt to explore facts on the grounds of a rational approach to include key informant interviews by involving selected groups of individuals who are likely to provide needed information, ideas and insights on the proposed research. Accordingly, in-depth interview was conducted among 7 key informants in order to obtain the desired results, and collect data on relevant source and well-informed sources that is relates with women's participation in NFA in the study area. According to Kumar (1989), key informant interviews to involve interviewing of knowledgeable individuals who are likely to provide the required information, ideas and insights on a particular subject. The time and place for key informant interview' was decided by the key informants themselves and the majority of interviews were held in the place they selected.

Direct Observation: The observation method is the most commonly used technique in collecting primary data since subjective bias is eliminated and the information obtained relates to what is currently happening; it is not complicated by either the past behavior or future intentions as Kothari (2004) stated. Direct observation helped to have a better understanding of the various phenomena under investigation. Observation is not about what people have written or what they have said, but it is what they are doing. Thus, this technique was carried out through personal observation in the field by preparing checklist, which was designed to generate data about the situation of the issue.

\title{
Data Analysis Techniques
}

In this study, both quantitative and qualitative data analysis techniques were employed and a combination of data analysis methods were required and carried out for this study. The quantitative data analysis is a process of tabulating, interpreting and summarizing empirical and numerical data for the purpose of describing or generalizing the population from the samples. Accordingly, descriptive and inferential statistics were used to analyze the quantitative data. Whereas, binary logistic regression model was used to examine the factors that determine the participation of women in NFA; because it is a powerful statistical tool as it allows us to determine the effect of independent variables on the dependent variable while holding any number of other independent variables constant. In relation to this, binary logistic regression is a form of regression that is used when the dependent variable is dichotomous or dummy and the independents are of any type (Dattalo, 2008). The variables that were collected in the questionnaire was continuous and categorical and used in the analysis were categorical via changing nature of variables since the nature of the outcomes of binary logistic regression result required the association test or chi-square test. For that reason, Chi-square test was used to examine the association of the categorical variables such as demographic factors, socio-economic factors, institutional factors and locational factors with the dependent variable. On the other hand, summarizing what was heard in the discussions on words, phrases or patterns were the major tasks that accomplished in the qualitative data analysis. Hence, the information that collected through key informants interviews, focus group discussions and observation was analyzed textually to complement the statistical results from the structured questionnaire.

\author{
Descriptions of Variables for Quantitative Section and Working Hypothesis \\ Dependent Variable (Explained variable) \\ Participation in Non-farm activity: The predicted or outcome variable of the study is participation in non-farm
}


activity. The nature of dependent variable is dichotomous or dummy variable. The dependent variable non-farm activity has two values. The values 1 represents if women's participated in non- farm activity and 0 , otherwise.

\section{Independent Variables and Working Hypothesis}

Predictors or explanatory variables are the variables that influence the predicted or dependent variable. In this study, the independent variables were assumed that determine the participation of women in non-farm activities. Based on the review of literature, the researcher identified the following determinant factors, which are the combination of demographic factors, socio- economic factors, institutional factors, and locational factors in the study area as shown below.

1. Age: is a variable expected to influence non-farm activity participation positively when age of women increases, their level of understanding and possibility of engaging in non-farm activity also increases. This means that, the adult age groups assumed more NFA participant than the young one.

2. Marital status: constitutes four marital status categories and stipulates whether respondents are single, married, divorced, and widowed. It is hypothesized that single, divorced or widowed type of marital status positively affects women's participation in non-farm activity. Because, these women do not have assistance from men's counterpart and take the responsibility of both income generating and household tasks; increase their engagement in non-farm work decisions.

3. Family Size: It is the variable refers to the number of family members in the household or in one roof: hypothesized that if women with in household size large, their participation in non-farm activity might increase.

4. Educational status: Education is a potentially important determinant of NFA. Education improves an individual's prospects for non-farm jobs as well as increases the ability to allocate time to work efficiently among income producing activities. It is expected to have a positive impact on non-farm activity participation.

5. Status of Household: It is a dummy variable of either male-headed household or female-headed household. It is expected that women in female-headed household would have a better participation in non-farm activities: since they are a sole income earner that takes the household responsibility to generating income for their household through different income generating tasks

6. Landholding size: It is the variable refers to the size of land holding operated by the household measured in Hectare. It is expected that positively influence the probability of participating in non-farm employment. The probabilities of participating in NFA increase, when women who have large land size since it used as the motivating factors to participate in NFA.

7. Access to formal credit: Accessibility of credit from a financial institution would facilitate the participation of women in NFA. Women who have access to credit would more propensity to be involved in NFA, while women who have would less propensity to engage in NFA. Thus, it is expected that a positive influence on women towards non-farm activity participation.

8. Access to non-farm training: It is dummy variable and most of the non-farm activities being skill based; training increases the possibility of getting non-farm jobs. Hence, if they have access to non-farm skill training, it is expected to have a positive influence on their participation in NFA.

9. Membership of Social groups: It is dummy variable and refers to the ability of engagement in a certain community association or village and social groups. It is hypothesized that membership of social groups affects the participation of women in NFA positively. When women could become membership in a certain social group, they would get market information and sharing experiences from others.

10. Access to Water Supply: It is a dummy variable and the presence of rural water supply expected to have a positive influence on the participation of women in rural non-farm activity.

11. Having triple gender roles: It is a dummy variable and it refers the presence of combination of roles in the household and it is hypothesized to have negative impact on women to their non-farm work decisions since they busy with household obligations; they have no time for economic opportunities when women having a combination of roles at a time.

12. Distance to the nearest Main Road: It is hypothesized that, when the women's village is far away from the main nearest road, it might affect their participation in NFA negatively. However, if women village is the nearest to the main road, it would increase their mobility and communication, which enables them to be engaged in nonfarm work.

13. Distance to the nearest main Market: The distance of product market from the household, residence is measured in the inhabitants (women in this study) walking times of her and then converted into Km. It is hypothesized that, when women's village is far away from the main product market, it might affect their participation to NFA negatively. This is because; women would not have time to go a long distance due to domestic chores. 
Table 3.2 Descriptions of Explanatory Variables Used in Binary Logistic Regression Model

\begin{tabular}{|l|l|l|}
\hline Variables & Variable Description & Variable Code \\
\hline Age of women & $\begin{array}{l}\text { Categorical Variable,1 if a woman has age 18-29,2= between } \\
30-41,3=42-53,4=54-65, \text { and } 5=>65 \text { years of age }\end{array}$ & Agecat \\
\hline Marital status & $\begin{array}{l}\text { Categorical variable:1 if a woman is Unmarried, 2=if Married, } \\
\text { 3=if Divorced, and 4=if widowed }\end{array}$ & Maristat \\
\hline Family size & $\begin{array}{l}\text { Categorical variable:1 if woman household has 1-3 family } \\
\text { size,2=if 4 up to 6,3= if woman has }>6 \text { family size }\end{array}$ & Famsize \\
\hline Educational level & $\begin{array}{l}\text { Categorical variable: } 1 \text { if a woman is illiterate,2=if a women can } \\
\text { read and write,3=if a woman has primary education, and 4 =if } \\
\text { secondary education or above }\end{array}$ & Edulevel \\
\hline $\begin{array}{l}\text { Status of } \\
\text { household }\end{array}$ & $\begin{array}{l}\text { Dummy Variable:1 if woman household is male headed, and } \\
\text { 2=if female headed }\end{array}$ & Stathhd \\
\hline Landholding size & $\begin{array}{l}\text { Categorical Variable:1 if women household have cultivated land } \\
\text { size of }<0.5 \text { hectare,2=if } 0.51 \text { upto1 hectare, and 3=if }>1 \text { hectare }\end{array}$ & Landsize \\
\hline Access of credit & $\begin{array}{l}\text { Dummy Variable:1 if women obtained formal credit, and 0=if } \\
\text { not }\end{array}$ & Accesscredt \\
\hline $\begin{array}{l}\text { Access of Non -farm } \\
\text { training }\end{array}$ & $\begin{array}{l}\text { Dummy Variable:1 if a woman obtained non-farm activity } \\
\text { training, and 0=if not }\end{array}$ & Accesstraining \\
\hline $\begin{array}{l}\text { Membership of Social } \\
\text { Groups }\end{array}$ & $\begin{array}{l}\text { Dummy Variable:1 if women are membership in social groups, } \\
\text { and 0=if not }\end{array}$ & Membingroup \\
\hline $\begin{array}{l}\text { Access of } \\
\text { supply }\end{array}$ & $\begin{array}{l}\text { Dummy variable:1 if women having access of water supply and } \\
\text { 0=if not }\end{array}$ & Wateracess \\
\hline Triple gender roles & $\begin{array}{l}\text { Dummy Variable:1 if a woman having combination of triple } \\
\text { roles and 0 if not }\end{array}$ & Tiplegenderol \\
\hline Distance to Main road & $\begin{array}{l}\text { Categorical Variable:1 if main road far from a woman residence } \\
<1 \text { Km,2=if 1-2 Km, and 3=if }>2 \text { Km }\end{array}$ & Distnearstroad \\
\hline Distance to Market & $\begin{array}{l}\text { Categorical Variable: } 1 \text { if the product market far away from a } \\
\text { woman residence }<4 \text { Km,2=if 4up to8 Km ,and 3=if }>8 \text { Km }\end{array}$ & Distmainmarkt \\
\hline
\end{tabular}

\section{The Model Goodness-of-Fit (GOF) in the Study}

For attempting to know the model goodness of fit, it needs to examine the adequacy of the model before the estimated function becomes a permanent part of the decision-making apparatus as Johnson \&Wichern (2007) stipulated. Once a model has been developed, it is necessary how effective the model is in describing or denoting that the predictor variables select has a combined effect on the outcome variable. This is referred to as goodnessof-fit. In this study, omnibus test was used to compute the fitness of predictor variables to outcome variables. So, the omnibus test of model coefficients had chi-square values of 260.479 with 24 degree of freedom and a highly significant at $\mathrm{p}<0.05$, i.e 0.000 , denoting that the predictor variables selected had a combined effect on predicting the participation of women in NFA(Appendix,vi).

In this study, Hosmer and Lemeshow test was employed to evaluate the adequacy of logistic regression model since Hosmer and Lemeshow test is an approach used to evaluate model fitness or to compute a goodness-of-fit statistics. So, the Hosmer and Lemeshow goodness -of fit had a chi-square value of 2.884 on 8 degrees of freedom, and significant at $\mathrm{p}>0.05$, i.e. 0.941 , vindicated that logistic model has a goodness -of- fit (Appendix, vi).

These are formal tests of the null hypothesis that the fitted model is correct, and their output is a $p$-value-again a number between 0 and 1 with higher values indicating a better fit. In this case, however, a $p$-value below some specified alpha level (say, 0.05), it indicate that the model is not acceptable as Paul (2014) indicated. That is, if the Hosmer and Lemeshow Goodness-of-Fit test statistic is 0.05 or less, we reject the null hypothesis that there is no difference between the observed and predicted values of the dependent; if it is greater, as we want, we fail to reject the null hypothesis that there is no difference, implying that the model estimates fit the data at an acceptable level. It divides subjects into deciles based on predicted probabilities, and then computes a chi-square from observed and expected frequencies (Agresti, 2002; Paul, 2014).

\section{Issues of Reliability and Validity}

Reliability refers to the consistency, stability and repeatability of the results, i.e. the result of a researcher is considered reliable if consistent results have been obtained in identical situations, but different circumstances (Twycross and Shields, 2004). Similarly, validity is the extent to which any measuring instrument measures what it is intended to measure (Thatcher, 2010).

Thus, the researcher has conducted pretest to assure the reliability of the study among 20 respondents before 
the execution of actual study. This helped to avoid ambiguity of questions and know the level of understanding among respondents. In addition, Chronbach alpha was employed since it measures the internal consistency of the instrument or to test the reliability of the study. Therefore, the reliability of test statistics to women's participation on NFA indicates that the questions were reliable at Cronbach Alpha value of 0.816.

Similarly, solution for assuring the validity of the study, the researcher has employed multiple source of information, establishes a chain of evidence, and had key informants' review reports. Principally, a copy of interview schedule was submitted to advisor to examine the items, and number of questionnaire measures the concept or construct of interest (content validity). Experts also added some constructive ideas to improve the structured questionnaires and discussion guides to be focused and to avoid some unnecessary content. Thus, some useless, repeated or redundant and ambiguous items were omitted and items were according to standards in terms of adequacy, structuring and sequence of ideas. Moreover, the researcher has employed triangulation via data sources, and thick description to convey finding and to complement statistical results with qualitative part of the study. Generally, questions in the instruments were developed based on the review of literature regarding the issue. In addition, findings and results from the study were interpreted in relation to the review of the literature and previous research study for the purpose of analytical generalization. Furthermore, the use of mixed research approach increases the validity and strength the result of this study to complement statistical data.

\section{RESULTS AND DISCUSSION}

\section{Demographics and Socio-Economic Characteristics of Respondents'}

This study tried to compose different sample household corresponding with various demographic and socioeconomic characteristics of respondents. This is due to the fact that the composition of rural non-farm activity shows heterogeneity in the background characteristics and socio- economic characteristics of women in rural areas. Hence, a description of background and socio economic characteristics of respondents is vital to give basic information about age, marital status, family size, educational status and status of the household head and land holding size of the respondents in the study area.

\section{Age, Family Size and Marital Status of the Respondents'}

The age distribution of the respondents is an important for determining the ability to participate in NFA. As presented in Table 1, the age composition of the respondents has five categories and it indicates that $11.6 \%$ of the respondents were found in the age range of 18 up to 29 years old. $23.2 \%$ of the respondents were in the age range of 30 up 41 years old. About $30 \%$ of the respondents were in the age range of 42 up to 53, while $19.9 \%$ of the respondents were in 54 up to 65 years old of age group. The result also showed that, 15.3\% of the respondents found in the age category of above 65 years of age. The result revealed that, age of the respondents fall into adult age of labor force. The data from discussants also confirmed that, most of the respondents who are in the age group of adult age were more participated in NFA relatively than other age group. Further, the data from informants confirmed that, women who are in the age range of above 65 years old had limited involvement due to their old age. The result implied that those women who were in the age category of 42- 53, $54-65$ years old had more probability of participation in non-farm activities than others age category. In order to see whether there is the association between women's age category and their participation in non-farm activities, chi-square test was employed. The results confirms that there was the significant association between women's age and their participation in non-farm activity $\left(\chi^{2}=28.990, \mathrm{df}=4, \mathrm{p}=0.000, \mathrm{p}<0.05\right)$.

As far as marital status of respondents concerned, it influences the participation of women in NFA. It is clear that unmarried, married, divorced and widowed have no equal participation in NFA. In this case, the survey results showed that majority of the respondents $(65.9 \%)$ were married women, while small numbers of the respondents $6.4 \%$ were unmarried women. The rest $14.6 \%$ of the respondents were divorced and $13.1 \%$ of respondents were widowed women. From the result, it can be concluded that majority of the respondents concentrated on married marital status. The data from informant's interviewee affirmed that, from marital status category unmarried women had more probability to participate in non-farm activities because they were free from husband restriction and had less domestic burden than married, divorced and widowed respectively. On the other hand, widowed and married women had less probability of participation in NFA because sometimes they inherited husband's property and had busier with both domestic chores and with farming activities respectively as the data from informants and discussants verified. The result also showed that widowed women had less probability of participation in NFA than women who were unmarried. In order to see whether there is the association between women's marital status and their participation into NFA, chi-square test was employed. The result confirms that there was the significant association between marital status and women participation in non-farm activity $\left(\chi^{2}=35.550, \mathrm{df}=3, \mathrm{p}=0.000\right.$, $\mathrm{p}<0.05)$.In case of family size, majority of the respondents $(44.9 \%)$ had four up to six members with in the household, $39.7 \%$ of the respondents had one up to three members in their family, and $15.4 \%$ of the respondents had more than six members of family in their household. From this result, it is possible to conclude that, majority 
of the respondents have at least four members in the household.

Table.1 Percentage distribution of respondents' response to age, marital status and family size (N=267)

\begin{tabular}{|l|l|l|l|}
\hline Variables & Frequency & Percentage (\%) \\
\hline Demographic Factors & Categories & & \\
\hline \multirow{5}{*}{ Age } & $18-29$ & 31 & 11.6 \\
\cline { 2 - 4 } & $30-41$ & 62 & 23.2 \\
\cline { 2 - 4 } & $42-53$ & 80 & 30 \\
\cline { 2 - 4 } & $54-65$ & 53 & 19.9 \\
\cline { 2 - 4 } & Above 65 & 41 & 15.3 \\
\hline \multirow{5}{*}{ Marital status } & Unmarried & 17 & 6.4 \\
\cline { 2 - 4 } & Married & 176 & 65.9 \\
\cline { 2 - 4 } & Divorced & 39 & 14.6 \\
\cline { 2 - 4 } & Widowed & 35 & 39.1 \\
\hline \multirow{5}{*}{ Family Size } & 1-3family members & 106 & 15.4 \\
\cline { 2 - 4 } & 4-6family members & 120 & \\
\cline { 2 - 4 } & $>$ 6family members & 41 & \\
\hline
\end{tabular}

Source: obtained from survey data, 2018

\section{Educational Background of the Respondents'}

As survey result inferred in Figure.2, almost half of the respondents (43.45\%) were illiterate, whereas $29.9 \%$ of the respondents could read and write, $19.48 \%$ had primary education (1-8); small number of respondents $7.1 \%$ had secondary education or above. From the result, it can be possible to conclude that majority of the respondents were illiterate and they had faced difficulty to engage in skilled-based NFA. Analogically, the qualitative result also vindicated that majority of rural women were illiterate and faced difficulty to engage in skilled based NFA. On the other hand, women who had primary and secondary education or above had involved in high return nonfarm activities such as trade and grain milling services. The result implied that illiteracy constrained women's probability of being involved in NFA, while better literacy seems to have helped to increase the probability of participation on NFA. The result also showed that women who had primary education and secondary education or above had more probability of participation in NFA than women who were illiterate. In order to see whether there is the association between educational level of women and their participation in non-farm activities, chi-square test was employed. The result showed that statistically significant association was observed between women's educational level and their participation in NFA $\left(\chi^{2}=26.654, \mathrm{df}=3, \mathrm{p}=0.000, \mathrm{p}<0.05\right)$.

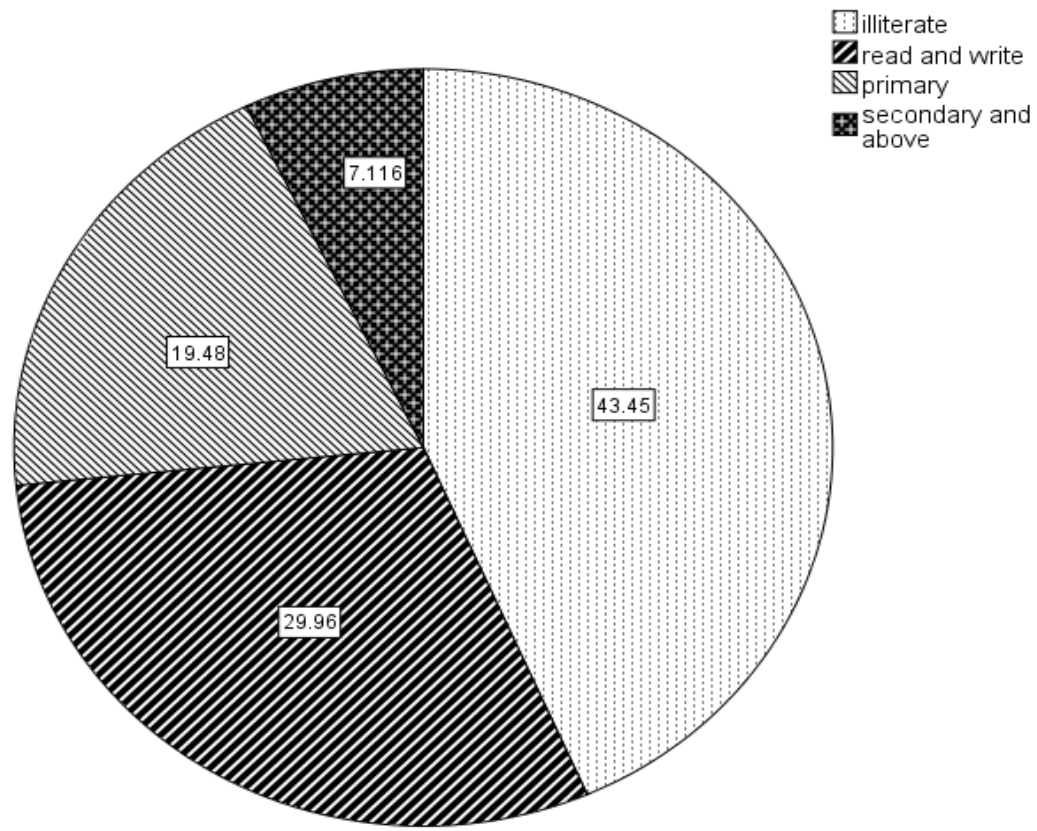

Fig: 2. Distribution of respondents' response based on their educational level Source: obtained from survey data, 2018 


\section{Respondents' Household head Status}

The survey result demonstrated that, majority of the respondents $(65.9 \%)$ were women in the male-headed household, while $34.1 \%$ were women in the female-headed household (Table .2). From the result, it can be inferred that, majority of respondent's falls into women in the male-headed households. Regarding to household status and women's participation in non-farm activities, the qualitative result from informants of this study vindicated that women in the male headed restricted from some activities in NFA due to husband restriction, because undertaking and involving in non-farm activity is given to people who have low or poor standard community. For example, sale of local drinks is also called female headed, having fear of getting this name majority of women in male headed constrained from involved in this type of activity. However, female-headed are free of husband restrictions and due to the absence of alternative income generating activities after divorce or her husband died, they are more engaged in NFA; even though female- headed household had responsibility to both income earning and head of household makes work burden. However, in quantitative, the net effect of status of household head was failed to reach significant to women's participation in NFA; this could be due to small numbers of female-headed household for this study. This finding inconsistent with Moser (1993), who finds out that due to constraints on their gendered role particularly in the household enterprises, where men recruit their wives to work unpaid in tasks such as sewing, weaving/spinning or food processing. Thus, women are mainly engaged in selling, dressmaking and personal services with their husbands command.

Table 2 Percentage distribution of respondents' response to status of household heads $(\mathrm{N}=267)$

\begin{tabular}{|l|l|l|l|}
\hline Variables & Options & Frequency & Percentages (\%) \\
\hline \multirow{2}{*}{ Household-head Status } & Male- headed & 176 & 65.9 \\
\cline { 2 - 4 } & Female- headed & 91 & 34.1 \\
\hline
\end{tabular}

Source: obtained from survey data, 2018

\section{Land Holding Size of Respondents'}

As can be inferred from Table 4.3, $15.7 \%$ of the respondents had less than 0.5 hectare of land owned, while about $35.2 \%$ of the respondents had owned the cultivated land size between 0.51 up to 1 hectare. The survey result also showed that, majority of the respondents $(49.1 \%)$ had owned cultivated land more than one hectare which is locally known as ( 4 timad in locality $=1$ hectare). From the result, it can be inferred that, majority of the respondents have land holding size of more than one hectare for cultivation that owned. The result implied that, they had better probability of involvement in non-farm activities to expand their non-farm business.

The data from participants without conforming indicates that, those women who had no land and less than 0.05 hectare had more participated in non-farm activities. This is due to the fact that non-farm activity is used as an alternative option of landless or who had limited cultivated land with low agricultural productivity, but limited for some non-farm work that needs collateral as discussants verified. While, informants emphasized that, land is vital natural capital, which used as collateral, buy necessary materials \&equipment's for non-farm activities, and use it also for working place as well. Having this advantage, those women who had more cultivated land had more probability to be engaged in NFA. The chi-square result confirms that a statistically significant association was observed between the size of landholding and participation of women in NFA $\left(\chi^{2}=57.956, \mathrm{df}=2, \mathrm{p}=0.000\right.$, $\mathrm{p}<0.05)$.

Table .3.Percentage distribution of respondents' response to size of land holding $(\mathrm{N}=267)$

\begin{tabular}{|l|l|l|l|}
\hline Variables & Categories & Frequency & Percentage (\%) \\
\hline Size of land holding & $0-0.5$ hectare & 42 & 15.7 \\
\cline { 2 - 4 } & $0.51-1$ hectare & 94 & 35.2 \\
\cline { 2 - 4 } & $>1$ hectare & 131 & 49.1 \\
\hline
\end{tabular}

Source: obtained from survey data, 2018

\section{Access to Rural Water Supply}

As can be shown from Table 4.4, a significant number of respondents (61.8\%) did not have the accessibility of water supply, while a small number of the respondents $38.2 \%$ had access of water supply. From the result, it can be concluded that, majority of the respondents had not have accessibility of water supply for non-farm work decisions. The qualitative result from informants and discussants also confirmed that, those women who had access to water supply had engaged in non-farm activity. This implied that the absence of water supply for women in residential constrained the probability of non-farm participation. Here again, informants of this study gave emphasized that the absence of clean water supply has a serious problem, especially in the lowland part (Abaslma and Karma Qolla kebeles) of the study area.

Even though, some kebeles have obtained pump water; the accessibility of water supply to all kebeles is limited. Informants also deemed that efforts were made to reduce the problem via digging pump water well to the community. However, due to the increment of rural population growth, majority of women fetching water with 
cumbersome situation, with conflict, time devote and crying their children in addition to long distance of water site. Hence, even though so many times announce to concerned bodies, our announcement simply taken as barking. Corroborate this study finding, the study of Adamu (2010) also indicates that the households travel more distances to get water or wait for long there, they are spending their productive time and energy. This is a big problem especially during dry seasons and drought years when local streams and springs fail to continue their usual discharge and is more severe in the lowland livelihood zone of Shebel Berenta Woreda. Mesay (2008) also founds out that non-farm activities are constrained by the lack of supporting basic rural infrastructure such as potable water supply and road network has rendered a huge impact on the livelihood activities of rural household. Chisquare result also confirms that the significant association was observed between access to water supply and participation in NFA $\left(\chi^{2}=30.850, \mathrm{df}=1, \mathrm{p}=0.000, \mathrm{p}<0.05\right)$.

Table 4. Percentage distribution respondents' response to access to rural water supply $(\mathrm{N}=267)$

\begin{tabular}{|l|l|l|l|}
\hline Variables & Options & Frequency & Percentage (\%) \\
\hline \multirow{2}{*}{ Access to rural water supply } & Yes & 102 & 38.2 \\
\cline { 2 - 4 } & No & 165 & 61.8 \\
\hline
\end{tabular}

Source: obtained from survey data, 2018

\section{Membership in Social Groups (Association)}

Table 4.5 depicts that majority of the respondents $(74.5 \%)$ were membership in social groups (have social network and association), while $25.5 \%$ of the respondents were not in any of those membership of social groups. From the result, it can conclude that, majority of the respondents' had a social network, relationships, association and groups. The qualitative result also confirms that those women who were a membership in social groups had actively participated in NFA.

However, in contrast to the above point, being membership of social groups also constrained from non-farm activity participation especially in handicraft (such as pottery, carpentry, blacksmithing, and leather works). This could be the fact that works of handicraft activities given to a certain community or belongs to lower class society. Taking into account, those who are membership in formal social groups (Iddir, Iqub, women's association) restricted from some activities in non-farm except themselves association as focus group participants verified. Consequently, the net effect of membership in social groups was insignificant to the participation of women in NFA. Chi-square test was employed in order to see whether there is the relationship between membership in social groups and participation of women in non-farm activities. The result signified that there was the significant association between becoming membership in social groups and women's participation in $\mathrm{NFA}\left(\chi^{2}=5.889, \mathrm{df}=1\right.$, $\mathrm{p}=0.017, \mathrm{p}<0.05)$.

Table 5 Percentage distribution of respondents' response to the membership in social groups $(\mathrm{N}=267)$

\begin{tabular}{|l|l|l|l|}
\hline Variables & Options & Frequency & Percentage (\%) \\
\hline \multirow{2}{*}{ Membership in Social groups } & Yes & 199 & 74.5 \\
\cline { 2 - 4 } & No & 68 & 25.5 \\
\hline
\end{tabular}

Source: obtained from survey data, 2018

Triple gender roles of Women's within the Household

The survey result demonstrated that, majority of the respondents (74.9) had a responsibility to undertake all triple gender roles in the household (Table, 4.6). From the result, it is possible to infer that, majority of the respondents had a combination of tasks or a responsibility to undertake productive, reproductive and community (management \&politics) roles that limit them to be engaged and active participant in NFA. On the other hand, $(25.1 \%)$ of the respondents had not responsibility to all triple roles. It can be concluded that, majority of respondents have a combination of roles in the household as the result reveals. This influences their probability of participation in their non-farm work decision due to time poverty since they have the combined effects of roles at a time. This result is consistent with the works of FAO, IFAD and ILO (2010), which indicates that the burden of combining productive and reproductive responsibilities inevitably affects their access to paid employment, often increases their stress levels and has an impact on power dynamics within households. These effects are not accounted in conventional notions of decent work, which tend to focus only on paid employment outcomes.

Concerned to see whether there is the association between women responsibility of triple roles and their participation in non-farm employment, chi-square test was employed. The result confirms that, there is a statistically significant association was observed between women triple gender roles and their participation in nonfarm activity $\left(\chi^{2}=45.438, \mathrm{df}=1, \mathrm{p}=0.000, \mathrm{p}<0.05\right)$. 
Table 6. Percentage distribution of respondent's response to triple gender roles $(\mathrm{N}=267)$

\begin{tabular}{|l|l|l|l|}
\hline Variables & Options & Frequency & Percentage (\%) \\
\hline \multirow{2}{*}{$\begin{array}{l}\text { Having the responsibility of undertaking all triple } \\
\text { roles in the household? }\end{array}$} & Yes & 200 & 74.9 \\
\cline { 2 - 4 } & No & 67 & 25.1 \\
\hline
\end{tabular}

Source: obtained from survey data, 2018

Institutional Characteristics of the Respondents'

Access to Non-farm Activity Training

As presented in Table 4.7, 32.2\% of the respondents had access to non-farm activity training. Similarly, from $(32.2 \%)$ of the respondents who obtained NFA training, $25.8 \%, 22.4 \%$, and $3 \%$ had obtained business management, service delivery and handicraft training respectively.

The result also showed that about $(67.8 \%)$ of the respondents reported that, they had not obtained any of the non-farm activity training at all. From the result, it can be concluded that majority of the respondents had not obtained non-farm activity training. FGD participants remarked the vitality of training to involve in non-farm employment especially in non-farm skill based activity, but nothing is new about training no one of responsible concerned bodies came to them to provide awareness about skill-based activities outside agriculture activities.

The focus group discussants also remarked that the absence of skill training is the main problem to participate in skill based non-farm activities. Informants also deemed that there is a problem of absence of skill training and explained that efforts would made to solve the problems through awareness creation to women in order to start non-farm business, how to attract customers and manage business. The result also showed that those women's who took training was found more participate in NFA than women's who did not take the skill training since skill training was important factor for women to involve in NFA. In the same vein, the result reported by Yishak et al.,(2014) indicates that non-farm skill training significantly influenced non-farm diversification strategies. Table 7. Percentage distribution of respondents' response to access to NFA training ( $N=267)$

\begin{tabular}{|l|l|l|l|l|}
\hline Variables & Options & Frequency & Percentage (\%) \\
\hline Access to non-farm activity training & Yes & 86 & 32.2 \\
\cline { 3 - 5 } & No & 181 & 67.8 \\
\hline \multirow{2}{*}{$\begin{array}{l}\text { Types of NFA } \\
\text { training }\end{array}$} & Handicrafts & Yes & 8 & 3 \\
\cline { 2 - 4 } & & No & 78 & 29.2 \\
\cline { 2 - 5 } & $\begin{array}{l}\text { Business management and/ } \\
\text { entrepreneurship }\end{array}$ & Yes & 69 & 25.8 \\
\cline { 2 - 5 } & Service delivery training & No & 17 & 6.4 \\
\cline { 2 - 4 } & Yes & 60 & 22.4 \\
\hline
\end{tabular}

Note: For the types of NFA training, multiple responses were recorded.

Source: obtained from survey data, 2018

\section{Access to Credit Services}

As presented in Table 4.8, a significant number of the respondents $(60.3 \%)$ had not access of credit services, while $39.7 \%$ of the respondents had obtained credit services. From this result, it can be possible to conclude that a significant number of respondents had not taken loan or obtained credit from institutions. However, from the respondents who taken loan or out of (39.7\%) respondents, 36.7\%, $25.8 \%$, and $4.5 \%$ had obtained credit from micro - finance institutions, bank and private lenders respectively. From the result, it can possibly argue that micro-finance institution is better than other institutions for women to access credit services in rural areas. In other speaking, majority of respondents obtained credit from micro-finance institutions $(36.7 \%)$ than banks and private lenders in the study area.

On the other hand, out of the respondents who had not obtained credit $(60.3 \%), 51.7 \%, 40.1 \%, 40.4 \%$, and $50.6 \%$ of respondents had not obtained credit due to the lack of collateral, high interest rate, short duration to return the loan and absence of credit institution respectively. From the result, it can be inferred that, majority of the respondents had not obtained credit due to lack of collateral from the institution followed by absence of credit institution in the study area. In corresponding, the result also demonstrated that higher interest rate and short duration to return the loan constrained women to get credit from the institution.

Hence, it implied that, the inability of getting credit from institutions poses the problems for many women to non-farm work decisions. The result also showed that the absence of access of credit services, the negative impact it had to the participation in non-farm activities for women. In line with this result, Kalalto (2016) study indicates that accessed to credit significantly determine peasants' decision on non-farm jobs. However, Kassie et al., (2017) study showed that, access to credit service affect it negatively decision to participate in non-agricultural livelihood diversification activities. 
Table .8 Percentage distribution of respondents' response to access of Credit $(\mathrm{N}=267)$

\begin{tabular}{|c|c|c|c|c|}
\hline \multicolumn{2}{|c|}{ Variables } & Options & Frequency & Percentage (\%) \\
\hline \multirow{2}{*}{\multicolumn{2}{|c|}{ Access of credit services }} & Yes & 106 & 39.7 \\
\hline & & No & 161 & 60.3 \\
\hline \multirow{6}{*}{ Sources } & \multirow[t]{2}{*}{ Micro-finance Institution } & Yes & 98 & 36.7 \\
\hline & & No & 8 & 3 \\
\hline & \multirow[t]{2}{*}{ Bank } & Yes & 69 & 25.8 \\
\hline & & No & 37 & 13.9 \\
\hline & \multirow[t]{2}{*}{ Private Lenders } & Yes & 12 & 4.5 \\
\hline & & No & 94 & 35.2 \\
\hline \multirow{8}{*}{ Constraints } & \multirow[t]{2}{*}{ Lack of collateral } & Yes & 138 & 51.7 \\
\hline & & No & 23 & 8.6 \\
\hline & \multirow[t]{2}{*}{ High interest rate } & Yes & 107 & 40.1 \\
\hline & & No & 54 & 20.2 \\
\hline & \multirow{2}{*}{$\begin{array}{l}\text { Short duration to return } \\
\text { the loan }\end{array}$} & Yes & 108 & 40.4 \\
\hline & & No & 53 & 19.9 \\
\hline & \multirow{2}{*}{$\begin{array}{l}\text { Absence of financial } \\
\text { institution }\end{array}$} & Yes & 135 & 50.6 \\
\hline & & No & 26 & 9.7 \\
\hline
\end{tabular}

Note: Respondents' responses to sources of credit and constraints to get credit were recorded multiple response.

Source: obtained from survey data, 2018

\section{Locational Characteristics of the Respondents'}

\section{Access of Road and its Distance to Residence of Respondents'}

As presented in Table 4.9,31.1\% of the respondents' residence is far from less than $1 \mathrm{~km}$ to the main road (which is always used for market). Similarly, $29.6 \%$ of the respondents responded that their home is far from the main road between the ranges of $1 \mathrm{~km}$ up to $2 \mathrm{~km}$. The result also demonstrated that, majority of the respondents $(39.3 \%)$ responded that their residence was more than $2 \mathrm{~km}$ far away from main road. From the result, it can be inferred that majority of the respondents had not have accessibility of road to non-farm participation in the study area. Discussants also verified that the inability of getting the main road easily had gotten difficulty to participate in non-farm activities. In contrast, women who have easily accessed the main road or near to the main road have active participant in non-farm activities easily. Hence, the result implies that, women's residential house far from the main road constrained their participation in NFA. Informants also deduced that accesses the road to all rural kebeles' was the main key tasks of the budget year, but still there is a problem of lagging behind within the government due to shortage budget and absence of the cooperation within the community.

From the words of informants, one explanation might lie in the fact that some the activities may not rely directly on the road access, and may rely more on local demand directly at the household location, for example sale of local drinks. Hence, the net effect of distance to main road was absence of significant difference to NFA participation. The result is consistent with the finding founds out by Minot et al., (2006); Mideksa(2015),which indicates that there is no statistically significant difference in mean walking time in hours to reach the nearest allweather road across household's income diversification strategies.

Table 9 Percentage distribution of respondents' response to the distance of the nearest main road to their residence (home) $(\mathrm{N}=267)$

\begin{tabular}{|l|l|l|l|}
\hline Variables & Categories & Frequency & Percentage (\%) \\
\hline \multirow{2}{*}{$\begin{array}{l}\text { How far your house to the nearest } \\
\text { main road? }\end{array}$} & $<1 \mathrm{~km}$ & 83 & 31.1 \\
\cline { 2 - 4 } & $1-2 \mathrm{~km}$ & 79 & 29.6 \\
\cline { 2 - 4 } & $>2 \mathrm{~km}$ & 105 & 39.3 \\
\hline
\end{tabular}

Source: obtained from survey data, 2018

\section{Distance of Nearest Main Market (DNMM)}

Access of market measured based on the inhabitants (women for this study) of the villages commonly travel to Yedwuha town to sell their outputs and buy necessities. Distance to market in the study context thus means the distance data first collected in minutes and converted to kilometers from each woman's residential homestead to Yedwuha town (Woreda major town) since their typical mode of transportation was walking. As it can be seen in Table 4.10, $14.2 \%$ of the respondents responded that their house far from the main market less than $4 \mathrm{~km}$. On the other hand, majority of the respondent's residence (44.9\%) are between the ranges 4 up to $8 \mathrm{~km}$ far away from the main product market. The result also indicated that $40.8 \%$ of the respondents' residence or houses are more than $8 \mathrm{~km}$ far away from the main product market.

From the result, it can be possible to conclude that majority of the respondents farther from the market and 
this implied that there is no accessibility of product market for women in the study area. The researcher also observes that the distance of the market is farther and it is difficult for women especially for women's who are found in Kolla kebeles.

Informants also accepted the problem of market accessibility to rural community to make access easily for product market. Even though efforts were made to solve the problem with expansion of market centers on ruraltown for accessibility, still the problem is not solved due to the absence of land and absence of cooperation among offices. Hence, the result implies that the absence of accessibility of market constrained women's ability to participate in NFA. This result is in agreement with the work of Yuanxiang (2017), Escobal (2001); Wen-Chi Huang et al., (2014); Kassie et al., (2017), which shows that in terms of location, the distance from the household's residence to the market is negative impact associated with the participation on NFA

Table .10 Percentage distribution of respondents' response to the DNMM from Home $(\mathrm{N}=267)$

\begin{tabular}{|l|l|l|l|}
\hline Variables & Categories & Frequency & Percentage (\%) \\
\hline \multirow{2}{*}{$\begin{array}{l}\text { How far your residence's to the main } \\
\text { market? }\end{array}$} & $<4 \mathrm{~km}$ & 38 & 14.2 \\
\cline { 2 - 4 } & $4-8 \mathrm{~km}$ & 120 & 44.9 \\
\cline { 2 - 4 } & $>8 \mathrm{~km}$ & 109 & 40.8 \\
\hline
\end{tabular}

Source: obtained from survey data, 2018

Table .11 Percentage distribution of respondents' response to the participation of women in NFA (N=267)

\begin{tabular}{|l|l|l|l|}
\hline Variables & Categories & Frequency & Percentage (\%) \\
\hline Participation in Non-farm Activity? & Yes & 136 & 50.9 \\
\cline { 2 - 4 } & No & 131 & 49.1 \\
\hline
\end{tabular}

\section{Determinant Variables of Women's Participation in NFLD in the Study Area}

The binary logistic regression model was employed to establish the relationships between participation in nonfarm activity and a set of explanatory variables. As Hulsizer and Woolf (2009) noted, binary logistic regression has become the preferred tool for predicting dichotomous outcomes in the social sciences because it is more flexible than any other model. Hence, binary logistic regression model was employed to establish the relationship between dependent (participation of women in NFA) and independent variables (demographic, socio-economic, institutional and locational factors) affecting women's participation in NFA in the study area. For that reason, 13 explanatory variables were selected to explain the dependent variable. However, seven independent variables (women's age category from 42-53 years old and age category 54-65 years old, widowed marital status category, primary and secondary education or above educational level, size of land holding, credit services, access to NFA training and having triple roles) were determinant factors influencing the dependent variable.

The Omnibus test of model coefficients had a Chi-square value of 260.479 with 24 degrees of freedom and a highly significant at $p<0.05$ i.e. 0.000 , denoting that the predictor variables selected had a combined effect in predicting the participation of women in NFA (Appendix, vi). The predictive efficiency of the model displayed that from all women included in the model, $91.4 \%$ respondents were correctly predicted. The sensitivity (correctly predicted participated women) and specificity (correctly predicted women not participated) were found to be $91.9 \%$ and $90.8 \%$, respectively (Appendix, vi). Therefore, the model is effective in describing the outcome variable. Principally, Hosmer and Lemeshow test with chi-square value of $2.884, \mathrm{df}=8$, the value of 0.942 which is significant at $\mathrm{p}>0.05$ vindicated that it has goodness-of-fit. Also, the Model summary demonstrated that (Pseudo $\mathrm{R}^{2}=0.831$ ), which means that the outcome variable explained by $83.1 \%$ via independent variables) (see Appendix, vi).

Accordingly, binary logistic regression result showed, women within the age group of 42-53, 54-65 years old increased their participation in NFA by the odds ratio of 12.421 and 27.253 as compared to $18-29$ years old respectively. That is, being other variables constant those women who are in the age group of women from 42-53 and 54-65 years of old more likely to participate in NFA than age groups of 18-29 years old and it had a positive relationship with participation in NFA. Hence, the net effect of women's age is a significant and positive relationship towards participation in NFA at $\mathrm{p}<0.05$ in all cases. Previous studies support this finding, Kassie $e t$ al., (2017) study shows that age is a significant relationship with the farm household decision to participate in nonagricultural livelihood diversification. Winching et al.,(2014);Bernardin(2012) studies also shows that age is a significant variable for non-farm work decisions.

The analysis also indicated that being other variables remain constant, widowed women less probability of participation in non-farm activities as compared to women who were unmarried. As the binary logistic regression result showed, the probability of participation of widowed women in NFA decreased by the odds ratio of 0.040 than those women who were unmarried since the result statistically significant relation at $\mathrm{p}<0.05$ in all cases. Hence, women's widowed marital status had negative relationship to non-farm participation decision. The result implied that marital status of women statistically significant relationship to probability of participation in NFA. Nevertheless, previous studies focus on the aggregate household probability of participation in NFA rather than 
women's participation; overlooked each marital status in NFA.

Table .12: Determinant Variables of Women's participation in NFLD in the Study Area

\begin{tabular}{|c|c|c|c|c|c|c|}
\hline Variables & Categories & $\mathbf{B}$ & S.E & Wald & Sig & Odds ratio \\
\hline Age & $\begin{array}{l}\text { 18- 29years old }(\mathbf{R C}) \\
30-41 \text { years old } \\
42-53 \text { years old } \\
54-65 \text { years old } \\
>65 \text { years old }\end{array}$ & $\begin{array}{l}.645 \\
2.519 \\
3.305 \\
1.564\end{array}$ & $\begin{array}{l}1.103 \\
.927 \\
1.057 \\
1.005\end{array}$ & $\begin{array}{r}.342 \\
7.380 \\
9.785 \\
2.420\end{array}$ & $\begin{array}{l}.558^{\mathrm{ns}} \\
.007^{*} \\
.002^{*} \\
.120^{\mathrm{ns}}\end{array}$ & $\begin{array}{l}1.907 \\
12.421 \\
27.253 \\
4.778\end{array}$ \\
\hline Marital status & $\begin{array}{l}\text { Unmarried (RC) } \\
\text { Married } \\
\text { Divorced } \\
\text { Widowed }\end{array}$ & $\begin{array}{l}.018 \\
-1.297 \\
-3.211\end{array}$ & $\begin{array}{l}1.682 \\
1.731 \\
1.124\end{array}$ & $\begin{array}{l}.000 \\
.561 \\
8.164\end{array}$ & $\begin{array}{l}.991^{\mathrm{ns}} \\
.454^{\mathrm{ns}} \\
.004^{*}\end{array}$ & $\begin{array}{l}1.018 \\
.273 \\
.040\end{array}$ \\
\hline Family size & $\begin{array}{l}\text { 1-3 family size }(\mathbf{R C}) \\
\text { 4-6 Family size } \\
>6 \text { Family size }\end{array}$ & $\begin{array}{l}-1.459 \\
-1.047 \\
\end{array}$ & $\begin{array}{l}.907 \\
.752 \\
\end{array}$ & $\begin{array}{l}2.591 \\
1.940\end{array}$ & $\begin{array}{l}.107^{\mathrm{ns}} \\
.164^{\mathrm{ns}}\end{array}$ & $\begin{array}{l}.232 \\
.351 \\
\end{array}$ \\
\hline $\begin{array}{l}\text { Educational } \\
\text { level }\end{array}$ & $\begin{array}{l}\text { Illiterate (RC) } \\
\text { can read and write } \\
\text { Primary education } \\
\text { Secondary \& above }\end{array}$ & $\begin{array}{l}.671 \\
2.500 \\
3.531 \\
\end{array}$ & $\begin{array}{c}1.127 \\
1.244 \\
1.349 \\
\end{array}$ & $\begin{array}{l}.355 \\
4.038 \\
6.854 \\
\end{array}$ & $\begin{array}{l}.552^{\mathrm{ns}} \\
.044^{*} \\
.009^{*} \\
\end{array}$ & $\begin{array}{c}1.956 \\
12.182 \\
34.154\end{array}$ \\
\hline $\begin{array}{c}\text { Status of } \\
\text { household head }\end{array}$ & $\begin{array}{l}\text { Male headed(RC) } \\
\text { Female headed }\end{array}$ & -2.776 & 1.549 & 3.211 & $.073^{\mathrm{ns}}$ & .062 \\
\hline Landholding size & $\begin{array}{l}<0.5 \text { hectare }(\mathbf{R C}) \\
0.51-1 \text { hectare } \\
>1 \text { hectare }\end{array}$ & $\begin{array}{l}2.737 \\
2.319 \\
\end{array}$ & $\begin{array}{l}.984 \\
.632 \\
\end{array}$ & $\begin{array}{l}7.746 \\
13.482 \\
\end{array}$ & $\begin{array}{l}.005^{*} \\
.000^{*} \\
\end{array}$ & $\begin{array}{l}15.446 \\
10.169 \\
\end{array}$ \\
\hline $\begin{array}{l}\text { Access of water } \\
\text { supply }\end{array}$ & $\begin{array}{l}\text { Yes(RC) } \\
\text { No }\end{array}$ & -1.084 & .631 & 2.949 & $.086^{\mathrm{ns}}$ & 0.338 \\
\hline $\begin{array}{l}\text { Membership in } \\
\text { Social groups }\end{array}$ & $\begin{array}{l}\text { Yes(RC) } \\
\text { No }\end{array}$ & -.125 & .662 & .035 & $.851^{\mathrm{ns}}$ & 0.883 \\
\hline $\begin{array}{l}\text { Having triple- } \\
\text { gender roles }\end{array}$ & $\begin{array}{l}\text { Yes(RC) } \\
\text { No }\end{array}$ & 2.034 & .736 & 7.633 & $.006^{*}$ & 7.647 \\
\hline Access of credit & $\begin{array}{l}\text { Yes(RC) } \\
\text { No }\end{array}$ & -2.670 & .616 & 18.784 & $.000^{*}$ & 0.069 \\
\hline $\begin{array}{l}\text { Access of NFA } \\
\text { training }\end{array}$ & $\begin{array}{l}\text { Yes(RC) } \\
\text { No }\end{array}$ & -1.426 & .631 & 5.115 & $0.24 *$ & .240 \\
\hline $\begin{array}{l}\text { Distance of } \\
\text { nearest-main } \\
\text { road }\end{array}$ & $\begin{array}{l}1 \mathrm{~km}(\mathbf{R C}) \\
1-2 \mathrm{~km} \\
>2 \mathrm{~km} \\
\end{array}$ & $\begin{array}{l}1.286 \\
.820 \\
\end{array}$ & $\begin{array}{l}.947 \\
.734 \\
\end{array}$ & $\begin{array}{l}1.844 \\
1.248 \\
\end{array}$ & $\begin{array}{l}.174^{\mathrm{ns}} \\
.264^{\mathrm{ns}}\end{array}$ & $\begin{array}{l}3.617 \\
2.271 \\
\end{array}$ \\
\hline $\begin{array}{l}\text { Distance of Main } \\
\text { market }\end{array}$ & $\begin{array}{l}<4 \mathrm{~km}(\mathbf{R C}) \\
4-8 \mathrm{~km} \\
>8 \mathrm{~km}\end{array}$ & $\begin{array}{l}1.292 \\
-.501 \\
\end{array}$ & $\begin{array}{l}1.503 \\
.737 \\
\end{array}$ & $\begin{array}{l}.739 \\
.463 \\
\end{array}$ & $\begin{array}{l}.390^{\mathrm{ns}} \\
.496^{\mathrm{ns}}\end{array}$ & $\begin{array}{l}3.639 \\
.606 \\
\end{array}$ \\
\hline Constant & & 1.910 & 1.684 & 1.287 & .257 & 6.752 \\
\hline
\end{tabular}

Source: Survey data, $2018 *$ Significant at $0.05, \quad{ }^{\mathrm{ns}}=$ not significant $\quad \mathbf{R C}=$ reference category

The Binary logistic regression result also showed, women having an educational level of primary and secondary or above as compared to those women who were illiterate, participation in NFA increase by odds ratio of 12.182 and 34.154 respectively. The result was statistically significant at $p<0.05$ in all cases. This means that women educational level of having primary and secondary or above had increased probability of participation in rural non-farm work decisions 12 times and 34 times than those women who were illiterate. The result implied that better literacy increase the probability of involvement, while illiteracy constrained women's engagement in NFA. Hence, women who had educational level of primary education and secondary education or above had significant positive relationship to participate in NFA.

This result is in agreement with the works of Atamanov and Berg (2011), which shows that better-educated individuals, especially with higher or vocational education, are more likely to choose pure non-farm activities or a mixture of farming and non-farming mostly because they are better qualified for formal non-farm jobs. Gordon and Craig (2001); Yuanxiang (2017) study analysis also indicates that education increases farm and non-farm productivity as well. Kalalto (2016) study also shows that the average educational level of households increases, the probability of non-farm employment also increase. In another ways, year of education more increases the probability of participation in NFA other than focusing in farming activity. Hence, an improvement in human capital has a positive impact on participation in NFA. 
The Logistic regression model result demonstrated that, being other variables constant, women who had the size of land holding in range of 0.51 up to 1 hectare and $>1$ hectare as compared to the size of land holding $<0.5$ hectare, the probability of participation into NFA increased by the odds ratio of 15.446 and 10.169 respectively. The result was statistically significant at $\mathrm{P}<0.05$ in all cases. This means that women who had land holding size of 0.51 up to 1 hectare and $>1$ hectare had more probability of participation towards non-farm activity than $<0.5$ hectare. Hence, the size of land holding was statistically significant positive relationship to participate in NFA. This result is consistent with the works of Kassie et al., (2017); Wen-Chin Huang et al.,(2014); Mecharla (2002), which indicates the land holding size had positive and significant relationship to NFA participation. However, this finding is in contrary to the previous studies of Yuanxiang (2017); Pavithra and Kamal (2013), they found out that size of land holding is insignificant factor of the participation in NFA.

The Binary logistic regression result revealed that, women who had no a combination of triple roles as compared to women having triple roles, the probability of being participate in NFA increased by the odds of 7.647. Put it in other way, women who had a combination of triple roles, the probability of being participated in NFA decreased by the odds ratio of $0.131(87 \%)$. This means that the women having a combination of roles in the household lead to work burden and time poverty; difficulty to participate in non-farm livelihood activities. The result was statistically significant at $\mathrm{p}<0.05$. Therefore, having a combination of triple roles in the household had significant relationship to non-farm activity participation. This result is in agreement with the works of UNDP (1995) cited in Ojulu (2015); Katega and Lifuliro (2014), which indicates that household obligations or gender roles affect non-farm participation.

Moreover, with respect to access to credit, women who had no access of credit less probability of participation in non-farm activity than those women who had access to credit. As the binary logistic result showed, women who had no access to credit, the probability of participation in NFA decreased by the odds ratio of 0.069 (93\%). This means that, the absence of credit services constrained women's non-farm participation decisions. The result was statistically significant at $\mathrm{P}<0.05$. Hence, access of credit services for women had significant relationship to nonfarm activity participation. This result is consistent with the study of Shehu and Abubaker (2015); Prowse(2015); Kassie et al., (2017), which indicates that access to formal credit is a significant relationship to the development of non-farm enterprises in rural areas and decision to participate in non-agricultural livelihood diversification. In grievance, the study of Mideksa (2015) showed that there was the absence of significant relationship between access to credit services and decision to participate in non-farm income diversification activities.

Lastly, concerned with access to non-farm training, women who had no access of NFA training had less probability of participation in non-farm activity than women's who have access to training for NFA. As the binary logistic regression result revealed, women who had not access of training for NFA, the probability of participation in NFA decreased by the odds ratio of $0.24(76 \%)$. This means that, the absence of NFA training constrained women's involvement in non-farm activity. The result was statistically significant at $\mathrm{P}<0.05$. Hence, the access to NFA training for women had a significant relationship to non-farm activity participation. In line with this result, Dilruba and Roy (2012) study also pointed out that there was a statistically significant relationship between nonfarm skill training and non-farm livelihood diversification.

\section{CONCLUSIONS AND RECOMMENDATIONS Conclusions}

Even though women play a significant role in non-farm economy, their participation is determine via different factors. It can be understand that, when determinants of women's participation in non-farm livelihood activity is still overlook, it leads to a continuous existence of poverty, food insecurity and unemployment as well as inability to spurring economic growth in rural areas. Hence, based on the finding of the study the following conclusions were drawn. Women literacy level, skill and knowledge to undertake non-farm activities is not adequate and they practiced non-farm activities with their background experience's and traditionally. In relation to this, the absence of technological support, absence of skill training, absence of rural water supply, long distance to main road and long distance of market retarded women not to have actively involved in NFA. Access to awareness creation and education, and non-farm skill training has an impact to attract a significant number of rural women to participate in non-farm activities in the study area.

The binary logistic regression result showed that women's age, marital status, educational level, size of landholding, having triple roles, access of credit services and non-farm training were the major determinants of women's participation in NFA in the study area. Accordingly, the young age and old age group, married and divorced groups of women, and women who were illiterate and women having a combination of triple roles were limited saying towards non-farm activity participation. On the other hand, the adult age group, single women, educated women, women who have large land holding size, access of credit and non-farm training were an active participant in non-farm activity. The result also indicates that there are no real effects of family size, status of household head, access of water supply, membership in social groups, distance to the main road and distance of the main market on women's participation into non-farm work decisions. This signals the need for giving due 
attention to the key variables or outcome variables as they have the vital role and contribution to women to be actively involved in non-farm employment in rural areas. Even though there was not statistically significant difference for women's participation in non-farm work decisions, the fact that women moderately participated or involved in NFA show that the needed to work more to be benefited from non-farm sector and to improve their livelihood outcomes.

\section{Recommendations}

Hence, based on the finding of this study, the following recommendations are forwarded by assuming that they could be important inputs for government and non-government organization to take into account the problems and to improve the situation:

$>$ The administrative officials and experts should provide awareness creation and adequate training for women about how to pursue non-farm income generating activities; not only for women, but also to all rural dweller's about non-farm income diversification since it has an impact on women's participation in NFA. The rural dwellers did not assume that activity is not found outside agriculture: having this, the outlook of the society towards handicrafts is negative. Hence, awareness creation and training also needed to negative outlooks and cultural myths, which assumed that handicrafts are works of lower class society and are not belong to men work only.

$>$ The governments have to adequately address the problems of local physical infrastructure, mainly electricity, road, water supply, market, public transport and telecommunication not only to women in non-farm participation but also to farming productivity as well. Since, lacks of infrastructure accessibility are the obstacle to women's participation in non-farm activity. In addition, locally preferable infrastructure should be built in accordance with the voices of the rural community in general and women's in particular for non-farm livelihood diversification and farm productivity.

$>$ Saving and credit institutions and expertise have to provide adequate credit services with minimum interest rate for a long period of time, expanding branches to easily access to all rural dwellers, with a simple procedure and free loan for pro - poor women so as to address their financial problems and to be involved more in non-farm income generating activities. In other words, women should be informed about how to obtain non-farm business, how to manage non-farm business and how to attract customers.

$>$ Women should be involved in a non -farm activity using local available materials and via updating their background skills since some activities, which are not required high amount of investment such as a sale, and processing of local drinks, leather works, sale of vegetables and fruits. In addition, women should request advisory services and should use available opportunities, which is provided by family members, institutions and government as well. This is because, there are some women hesitating to involve in NFA with suspicious belief and negligence; even though they have skills and available opportunities to be engaged in non-farm livelihood diversification.

\section{REFERENCES}

Adamu Teshome. (2010). Impact of Climate change on Household Water Security and on Sustainable livelihoods in Shebel Berenta Woreda, East Gojjam Zone, Amhara Regional State, Ethiopia. Unpublished MSC Thesis, Addis Ababa University.

Agresti, A. (2002). Categorical Data Analysis. Hoboken, New Jersey: Wiley.

Amugune, B.K. (2014). Sample size Determination and Sampling Techniques, Mental Health Workshop, Maanzoni, 15 October 2014.

Angell, B., and Townsend. (2011). Workshop for the 2011 Society for Social Work and Research annual meeting: Institute for Health, Health Care Policy and Aging Research of Rutgres: Rutgres School of Social Work.

Atamanov, Aziz., and Berg, Marrit van Den.(2011). Microeconomic analysis of rural non-farm activities in the Kyrgyz Republic: What determines participation and returns? Maastricht Graduate School of GovernanceWP-001 Maastricht University. Maastricht, Netherlands.

Barrett, Christopher.B, Reardon, Thomas., and Webb, P.(2001).Non-farm income diversification and household livelihood strategies in rural Africa: concepts, dynamics, and policy implications, Journal of Food Policy, 26 (4), 315-331.

Bernardin, Senadza. (2012). Non-farm Income Diversification in Rural Ghana: Patterns and Determinants. African Development Review, 24(3), 233-244.

Boserup, E. (1970). Woman's role in economic development. London: Allen \& Unwin.

Carolyn, S.R., and Isadore, N. (2008). Mixed methods research: Exploring the Interactive Continuum. Carbondale: Southern Illinois University Press.

Creswell, J.W. (2009).Research design: Qualitative, quantitative and mixed methods approach: 3rd (edition). University of Nebraska-Lincoln, Sage Publication.

Dattalo, P. (2008). Determining Sample Size. Balancing Power, Precision, and Practicality Pocket Guide to Social 
Work Research Methods, England: Oxford University Press.

Davis, Junior.R. (2003). The Rural Non-Farm Economy, livelihoods and their diversification: Issues and options. NRI Report No: 2753 Enterprise Trade and Finance Group Natural Resources Institute University of Greenwich at Medway United Kingdom.

Davis, Junior.R. (2006). Rural non-farm livelihoods in transition economies: emerging issues and policies, Journal of Agricultural and Development Economics, 3(2), 180-224.

Davis, J. R., and Bezemer, D. (2004). The Development of the Rural Non-Farm Economy in Developing Countries and Transition Economies: Key Emerging and Conceptual Issues. Chatham, UK: Natural Resources Institute.

Dilruba, Khatun., and Roy, B.C. (2012). Rural Livelihood Diversification in West Bengal: Determinants and Constraints. Institute of Agriculture, Agricultural Economics Research Review, 25(1), 115-124.

Ellis, F. (2000). Rural Livelihoods and Diversity in Developing Countries. Oxford: Oxford University Press.

Escobal, J. (2001). The Determinants of Non-farm Income Diversification in Rural Peru, World Development, 29(3): 497-508

FAO, IFAD and ILO. (2010). Gender dimensions of agricultural and rural employment: Differentiated pathways out of poverty Status, trends and gaps, Publishing Policy and Support Branch, Office of Knowledge Exchange, Research and Extension, Rome, Italy.

Gillham, B. (2000). The Research Interviews. Britain: MPG Books LTD.

Goitom Sisay and Kalpana Markandey.(2017).Female Headed Households' Participation in Peri-Urban Modern Small-Scale Irrigation Projects in Ethiopia, The Case of Kobo Town, Journal of Economics and Sustainable Development, 8 (3).

Gordon, Ann., and Craig, Catherine. (2001). Rural Non-farm Activities and Poverty Alleviation in Sub-Saharan Africa. Policy Series (14). Chatham, UK: Natural Resources Institute.

Hesse-Biber, S., and Leavy, P. (2004). Approaches to Qualitative research: A reader on theory and practice. New York: Oxford University Press.

Holmes, R., and Jone, N. (2010). How to Design and Implement Gender Sensitive Social Protection Program: ODI at 50 Advancing Knowledge Shaping Policy Inspiring Practices: Overseas Development Institute.

Hossain, Elias. Md., Shefa Zebun, S., and Islam, Khairul. Md. (2013). Participation of Rural Women in Farm and non-farm activities in Bangladesh, Journal of Economics and Development Studies, Vol 02, No.01.

Hugo Rämi. (2002). Fewer surpluses in Gojjam and Awi and Severe shortages in lowland areas of Abaye River Gorge, UN-Emergencies Unit for Ethiopia; UN-OCHA Assessment Mission, October 2002 (accessed 23 April 2009).

Hulsizer, M. R., and Woolf, L.M. (2009). A Guide to Teaching Statistics: Innovations and Best Practices. Chichester, West Sussex, UK: Wiley- Blackwell.

Israel, Glen. D. (1992). Determining Sample Size: Agricultural Education and Communication Department, University of Florida, IFAS Extension, PEOD (6) (Reviewed, 2003).

Johnson, A., and Wichern, W. (2007). Applied Multivariate Statistical Analysis, (6 ${ }^{\text {th }}$ ed).Upper Saddle River: Pearson prentice Hall.

Kabeer, N. (1994). Triple Roles, Gender Roles, Social Relations: The political subtext of gender training frameworks: Gender Hierarchies in Development Thought, Verso, London.

Kalalto G. (2016). Determinants of Employment Participation in Rural nonfarm activities. Journal of Poverty, Investment and Development, Vol 29:10-21. An International Peer-reviewed Journal.

Kassie, Geremew. W., Sangho, Kim., Francisco, P., and Fellizar, Jr. (2017). Determinant factors of livelihood diversification: Evidence from Ethiopia Environmental Studies/Research Articles, Cogent Social Sciences, $3: 1369490:$ https://doi.org/10.1080/23311886/2017.

Katega, I. M., and Lifuliro. C.S. (2014). Rural Non-Farm Activities and Poverty Alleviation in Tanzania: A Case Study of Two Villages in Chamwino and Bahi Districts of Dodoma Region. Research Report 14/7, Dares Salaam, REPOA Publisher.

Kothari, C.R. (2004). Research Methodology: Methods and Techniques, Jaipur, India, University of Rajasthan: New Age International.

Kumar, K.(1989).Conducting Key Informant Interview in Developing Countries; USAID Programme Design and Evaluation Methodology ,Report (13), Washington, D.C,USAID.

Lanjouw, Jean. O., and Lanjouw, P. (2001). The Rural Non-farm Sector: Issues and Evidence from Developing Countries. Journal of Agricultural Economics, 26 (1), 1-23.

Mecharla, Rao. P. (2002).The Determinants of Rural Non-Farm employment in Two Villages of Andhra Pradesh (India). Prus Working Paper No(12).Poverty Research Unit at Sussex, University of Sussex, Falmer, Brighton.

Mehta, G, S. (2002). Non-farm economy and rural development: Sponsored by Planning Commission Government of India, New Delhi: Giri Institute of Development Studies.Lucknow.

Mesay Kebede. (2008). Gender, Household Food Security and Coping Strategy: the case of Meskan Woreda of the Gurage Zone. Unpublished MSC thesis, Addis Ababa University. 
Mideksa, F. (2015). Factors Responsible for Income diversification among Farm households in Agarfa District, Bale Zone, Oromia Regional State, Ethiopia. Unpublished MSC thesis, Haramaya University, Ethiopia.

Minot, N., Epprecht, M., Ann, T.T., Trung, L.Q. (2006). Income diversification and poverty in the Northern Upland of Vietnam. Research report No.(145). International Food Policy Research Institute, Washington DC, USA.

Moser, C. O. N. (1993). Gender Planning and Development: Theory, Practice and Training, London: Rout ledge. Mphande, F.A.(2016).Infectious Diseases and Rural Livelihood in Developing Countries, Springer Science+ Business Media Singapore, Vol.(XV),187, p. 21,Springer Science Business Media Singapore.

Ojulu L. (2015).Gender Differences and Relations in Rural Household Livelihoods of Gog District, Anywaa Zone, Gambella Region, South Western Ethiopia, International Journal of Gender and Women's Studies, 3(1), 5179.

Osarfo, Daniel., Senadza, Bernardin., and Nketiah-Amponsah, E. (2016).The Impact of Non-farm Activities on Rural Farm Household Income and Food Security in the Upper East and Upper West Regions of Ghana, Theoretical Economics Letters, 6, 388-400, Scientific Research Publishing Inc.

Paul, D.A. (2014). Measures of Fit for Logistic Regression, Statistical Horizons LLC and the University of Pennsylvania, SAS Global Forum Paper 1485-2014, Philadelphia.

Pavithra, S., and Kamal, V. (2013). Role of Non-Farm Sector in Sustaining Rural Livelihoods in Punjab, Agricultural Economics Research Review, 26 (2), 257-265.

Reeves, H., and Baden, S. (2000).Gender and Development: Concepts and Definitions: Prepared for the Department for International Development (DFID) for its gender mainstreaming intranet resource, BRIDGE (development-gender), Report No-55, Institute of Development Studies, University of Sussex, Brighton, UK.

Reka, Sundaram-Stukel., Klaus, D.,and Songqing, J. (2006). Fostering growth of the rural non-farm sector in Africa: The case of Tanzania: Selected Paper prepared for presentation at the American Agricultural Economics Association Annual Meeting, Long Beach, California, July 23-26, 2006.

Sara Worku. (2007). Livelihood strategies of rural women with emphasis on income diversification and demographic adjustment: The case of Wolonkomi, Oromia region .Working papers on population and land use change in central Ethiopia, nr.(9) Addis Ababa University.

Shebel Berenta Woreda Communication Affairs office (2007- 2009 E.C). Shebel Berenta Woreda Agriculture and Rural development office: A Report on Food security and Social protection program Annual report: Amharic Version.

Shebel Berenta Woreda Communication Affairs Office. (2017).Shebel Berenta Woreda Rural Kebeles, Demographics and Socio economic features and Agro ecology report: Amharic Version.

Shehu, Abdulaziz., and Abubaker, Nura. (2015). Determinants of Participation of Farm households in Non-Farm Enterprises Activities in Rural Nigeria. International Journal of Economics, Commerce and Management: Vol. III, Issue 6, United Kingdom.

Singh, Ajay. S., and Masuku, Micah. B. (2014). Sampling Techniques and Determination of Sample size in Applied Statistics Research: An overview. University of Swaziland, Luyengo, Swaziland, International Journal of Economics, Commerce and Management, Vol. II, Issue 11. United Kingdom.

Stephen, Kwadwo. A., and Kasim, Hamza.(2015).Qualitative and Quantitative Research Paradigms in Business Research: A Philosophical Reflection, European Journal of Business and Management,7(3).

Thatcher, R. (2010).Validity and reliability of quantitative electroencephalography (QEEG). Journal of Neurotherapy, 3(14), 122-152.

Twycross, A., and Shields, L. (2004).Validity and reliability -What's it all about? Part 2 Reliability in Quantitative studies, Pediatric Nursing, 16 (10) p.36.

Victor, J. (2006). The SAGE Dictionary of Social Research Methods. (Ed.). London: SAGE Publications Ltd.

Wen-Chi Huang., Raju, Ghimire., and Rudra, Bahadur.S.(2014).Factors Affecting Non-farm Income Diversification among rural farm households in Central Nepal, International Journal of Agricultural Management and Development, 4(2): 123-132.

Worku Ifa. (2016). Livelihood Diversification as Household strategies: A case study of rural kebelles around Gelan Town, Oromia, Ethiopia. Unpublished Master thesis, Addis Ababa University, Addis Ababa, Ethiopia.

Yishak Gecho, Gezahegn Ayele, Tesfaye Lemma, Dawit Alemu.(2014). Rural Household Livelihood Strategies: Options and Determinants in the Case of Wolaita Zone, Southern Ethiopia. Social Sciences, 3(3), 92-104.

Yuanxiang, Liu. (2017)."Pushed out or pulled in? Participation in non-farm activities in rural China", China Agricultural Economic Review, Vol. 9 Issue:1.pp.111-129. 


\section{Appendix}

Appendix: Vi. Binary Logistic Regression Output

Omnibus Tests of Model Coefficients

\begin{tabular}{|c|c|c|c|c|}
\hline & Chi-square & Df & Sig. \\
\hline & Step & 260.479 & 24 & .000 \\
\hline & Block & 260.479 & 24 & .000 \\
\hline & Model & 260.479 & 24 & .000 \\
\hline
\end{tabular}

Model Summary

\begin{tabular}{|l|r|r|r|}
\hline Step & $\begin{array}{c}-2 \text { Log } \\
\text { likelihood }\end{array}$ & $\begin{array}{c}\text { Cox \& Snell R } \\
\text { Square }\end{array}$ & Nagelkerke R Square \\
\hline 1 & $109.568^{\mathrm{a}}$ & .623 & .831 \\
\hline
\end{tabular}

a. Estimation terminated at iteration number 7 because parameter estimates changed by less than .001 .

Hosmer and Lemeshow Test

\begin{tabular}{|l|r|r|r|}
\hline Step & Chi-square & Df & Sig. \\
\hline 1 & 2.884 & 8 & .941 \\
\hline
\end{tabular}

Classification Table ${ }^{\mathrm{a}}$

\begin{tabular}{|r|ll|r|r|r|}
\hline & Observed & & \multicolumn{3}{|c|}{ Predicted } \\
\cline { 4 - 6 } & & & $\begin{array}{c}\text { Participation in Non - } \\
\text { farm activity }\end{array}$ & $\begin{array}{c}\text { Percentage } \\
\text { Correct }\end{array}$ \\
\hline & & & No & Yes & \\
\hline Step & Participation in Non -farm activity & No & 119 & 12 & 90.8 \\
1 & Oes & 11 & 125 & 91.9 \\
\hline
\end{tabular}

a. The cut value is .500 


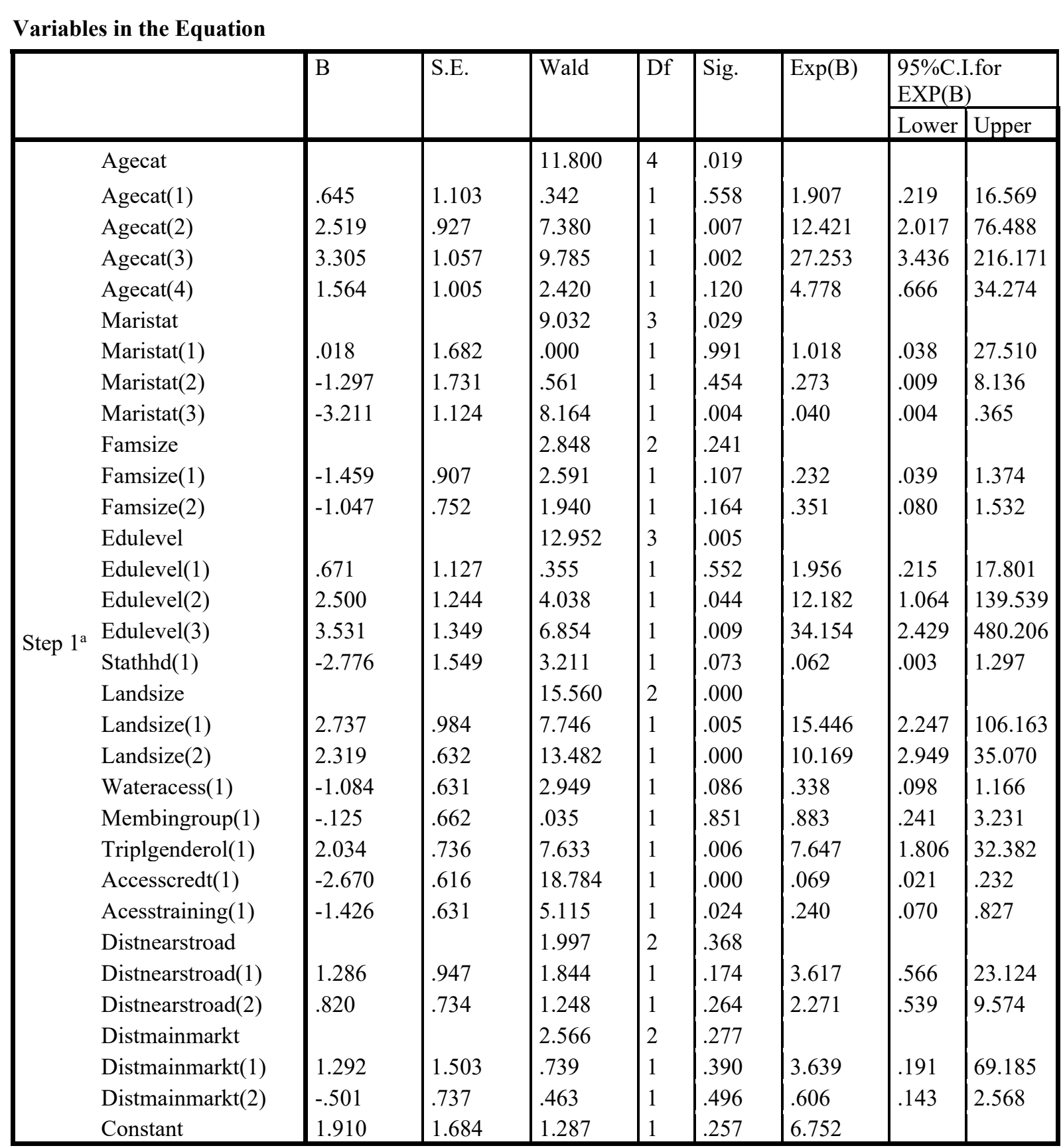

a. Variable(s) entered on step 1: Agecat, Maristat, Famsize, Edulevel, Stathhd, Landsize, Wateracess, Membingroup, Triplgenderol, Accesscredt, Acesstraining, Distnearstroad, Distmainmarkt. 